（121）述但帖及永吉 法别鑑/族菌桿痢赤

子族 他 養

卞, 形基 ち

肉鑑学三京

中二及相、

毒 就 生 等 ぱ

キ 物 $三$

膓 精學キち

咨密上灰亦

于湘白亭

鼠儿類色、

万研似鼠

ふ䥊 七 滀ち

す

及于 點 七す

豚波頗儿、

$己$ 從儿菌膓

机 ツ多苔炎

万テ シ 学

助 助

手乎京

ち

大

腸 寸

人種茲形前䠰路都

病々。三成通學學箱

原人於 シ 大 大

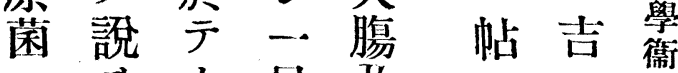

八 カ 見及

生生諸之赤。佐永學

物 ズ學

學ル者ガ桿 彥福

亚二相 識 菌

三至踵 別 族

免证

疫劣苦皆 郎 郎

先

武 ら

涮 ち

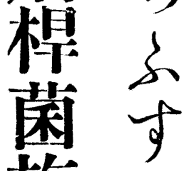

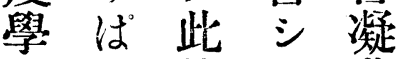

的 5 等 $么$ 㭉

觀ち 菌 其 培

四 太

族

鼠

鑑 方

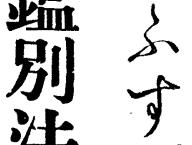

法

二腹

就炎

テ 热

通 
げ|補、集染ビ互い!ら サ察

んち體ご素色溶三にちン

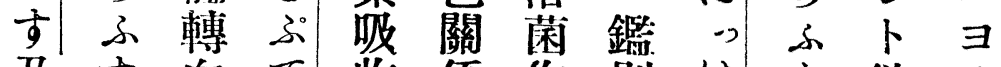

及向向て收係作別け卞欲少

三及作引試並用方公桿 七區

三は用、驗三三能培菌り別 他

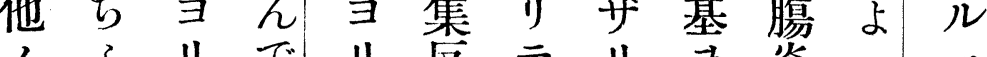

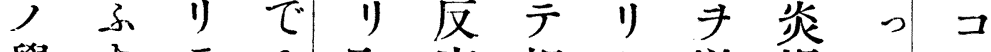

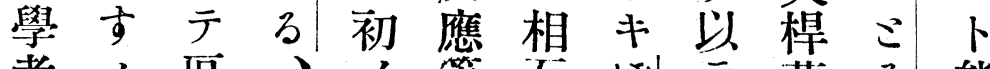

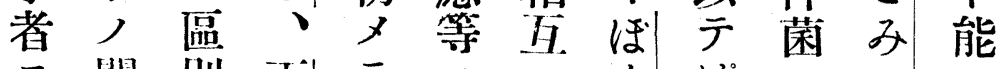
三關別头テ三三んは将, 反係七。兒明於分ほら全る ズ シ ス 及力テ示1 テラ卜小二八得及的同了二 此今企島區ばザモす一方 三省テ並別 5 少此桿種形今 種抗 シ 三 方 ノ 議 モ ぐ|得ふ西要心゙ル學 數 病士遂り ル古野菌 Iコ檢了 原キ三ぐコ桿 父種型コ香學

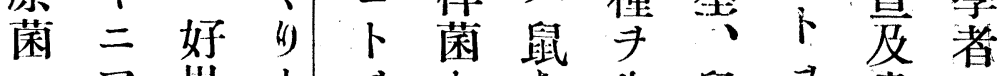
八ア果! 斗占方生鼠手患公 形亏兵報明子物䒓主者同 態ズ納っぜ力方學ふ張血— 學多么ちリナ桿的す寻清種 及クル 生, 八區八香菌く集モ

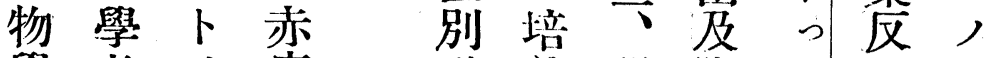
學者 痢點養凝腸ち應ナ 的八得桿 鑑じザ菌形反棉る結卜 識

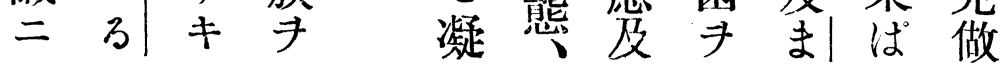


（123）述郎四崖佳帖及郎太福永吉

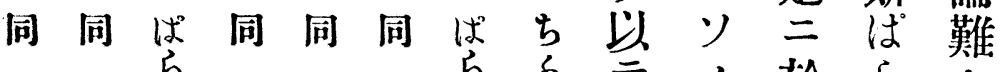

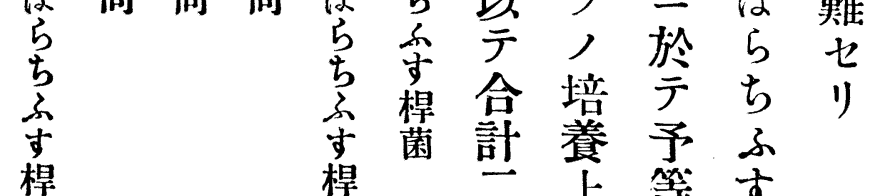

貝的 㷋

7 的是斯 論

相上等 す 菌菌古六公及 1 八形此赤 型型種態 等 痢 ノ學 菌 桿 菌及種 菌 き总, 族 試疫暴ノ 驗 學 同 鑑

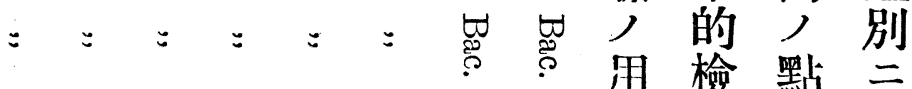
用 檢 點 三

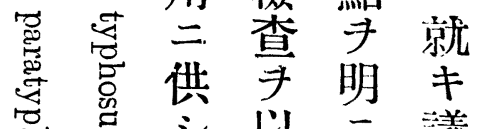
方 三 議 夕 テ シ 論 少比以 紛 即較テ名 于 研 鑑 卜 究 別、 三 キ キ テ 行容底 八易 正 リナ ス 予ラル 等 シ 處 八メ チ 此 $ン$ 知 

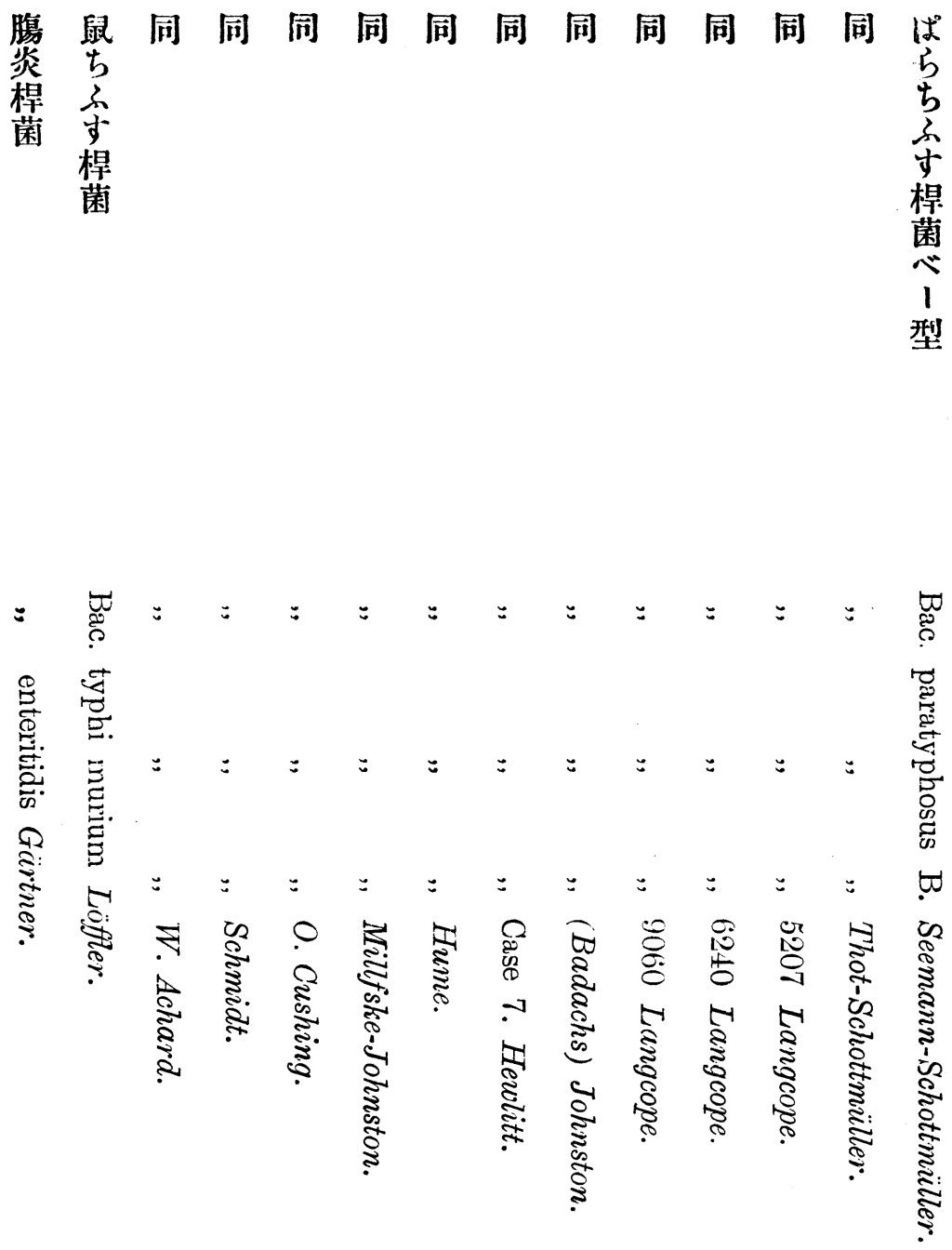
（125）逃郎四荠佳帖及郎太福永吉

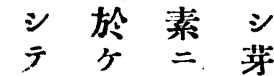

此 ル着胞記

等 $\exists$ 色 $\exists$ 三

, 音形 $\overrightarrow{+}$

菌入〈゙成分

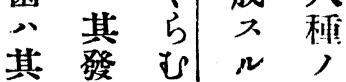

體县法 コ菌

甚 $=1 心$

全 $\boldsymbol{y}^{\prime}+$ 何

周不り》v

圍良方六正

$\exists$ 三脫十兩

リ 的色度 端

十 天 入, 鈍

乃 其 而 溫 圓

至適 $シ=ナ$

十溫テテル

共無 三 短

條三酸南桿

,干素分牀

鞭七, 時菌

毛度氣間

于于中加

出

然 $>$ 天 腹

活

潑 $ト$ 厂

ナモモキ良

ル室能八二

運溫号確

動二發實

$\exists \boldsymbol{P}$ 南

營り 営 死

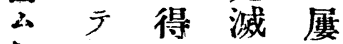

如 $E$ 下

斯 亦 雖 普 長

此能 F通 絲

等 $D E$ あ 狀

發酸に態

菌管素

種入年 久 現

八而二色分
是

t

普同同同同赤

第

通

秼

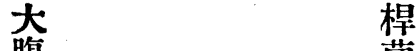

腸

桿

苗

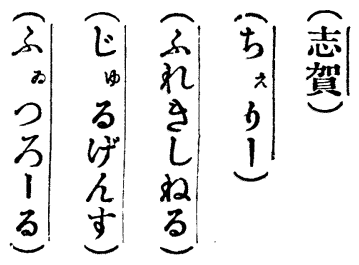

整

的

檢

查

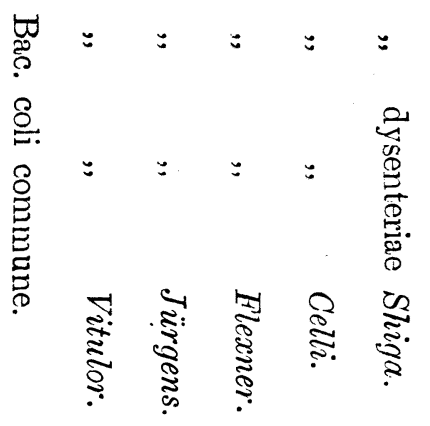


人大如 初

强脢次 $\neq$ 丈今

弱桿二聚小

及菌ぱ落點及

聚了5 5 狀

落該 占形漸 桿

人培尔成次菌

大養卞 $シ$ 圓

小基 桿 深 形 就

> = 菌 部 $\neq$

差於 あ)

異 51 モ 培

$ア 儿$ 型, 中養

儿狀去八央基

ノ態ぱ圓》こ

三贸占暗於

$ナ$ 古或色

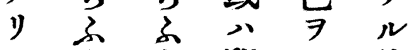

寸生 带 狀

桿 桿 圓 ビ 態

菌菌形周

ブ二緣 檢

У 1 シ

$\checkmark$ 型 透

卜黄明二

比鼠色 = 二

入亦带度

ルす斿了

二桿 實 媲

殆菌質 狀 所

之八或

ト膓 僅 八テ

相焱力波一

類程二狀 日

似菌顆 $\exists$,

侧、粒呈 後

大赤狀 涪

差 痢 $\exists$ 恰 在

ナ程呈无 性

n菌七葡,

只及

發普葉厂
上

二 前

於 記

万 三

卉

狀 入

態 程

$\exists$ 菌

記

述境

一七 䍱

阿左上

膠, 關

尔 如 係

板

培

7

以

比

比

較

檢

查

马

行

七

シ

二

殆

ン

F

相

致

ス

ル

$\exists$

見

夕

J

今

各

培

養

基
備 す 形

七桿態

ズ 菌 學

此, 上

等 如 何

等

點 活 區

二潑 别

於ナ

厂 $\bar{~}$

普 ズ 點

通 $又$

垃大赤

腹 痢 7

楿菌 認

菌族

及 能

赫 活

痢 潑

桿子但

菌 几

族 分 普

八子通

聊運大

力動 腹

他 7 㮛

, 有菌

諸

菌 1.

卜 雖万

區 ド至

别飞元

棝 條

得有

ル運 靴

)動 毛

ミ

ナク有

》且

ッ蓮

鞭 動

毛

$\Rightarrow \hbar$

具 5 
（127）述郎四意传帖及郎太福永吉

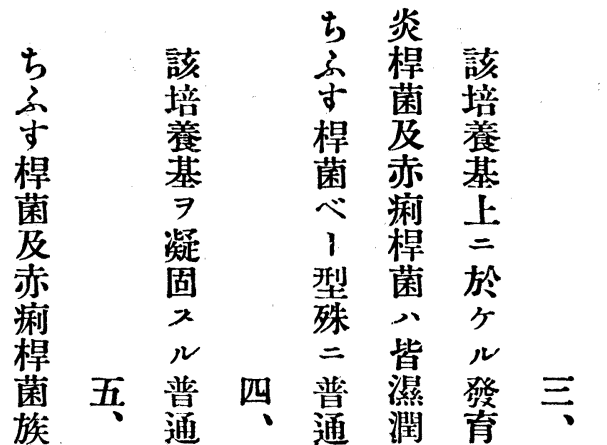

别光

ス次旌 該

ル $\boldsymbol{P}$ 培

二他 飱

卜ノ菌基

能 二苔 上

$\therefore+7=$

ズ 开於

程成宁

菌 シ ル

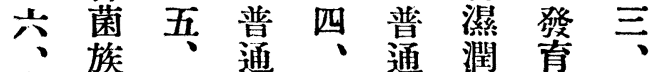

结 $\exists$ 莆大牛大光狀䭴

b除萄腸孚腹澤態鈴

力 $₹$ 糖及乎桿 $>$ 薯

b他凝腸培菌 檢培

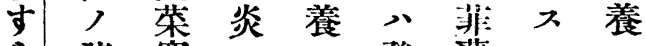

马諸穿少發溥ル

1菌刺二姢ナ

及 心培 桿

遗悉 養 菌

旺 ル ち

盛 灰交

藤 ク

二白す

培 該

該除

䓹

培手

除 シ色桿

キ テ 灭 菌

養他

厚至、

基

キ 帶ば

$=\quad$ 二 菌 黄 ら

於 t

西采

死和

斯

э 菌

發 八

苔灰ち

形色多

成菌桿

菌成菩菌

生

悉

之

凝

固

ル $\ni$ क

該水發登二

培 八狀凝

養透態荣

基明 $\exists$ 斜

上 $=$ 喕

二 シ 及 畫

於 テす鼣

少桿培

儿量菌竟

狀, =

態 沈 就

渣 ₹

万 7 テ

久有 記

す七述

桿り七

菌采

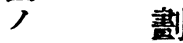

ソ 線

$\checkmark=$

下沿

比 7

ス

差 形 1

成 型

較 厅

ス 消

ル澤

二 濕

區 鼠

别

站

難 主

キ 桿

モ菌

蝹

全潤

ク灰

相白

等 色

シ 透

嵒

明 
ザガ 及 菌 藏二箱 只

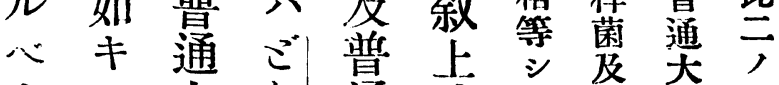

力七大り通培米腹培

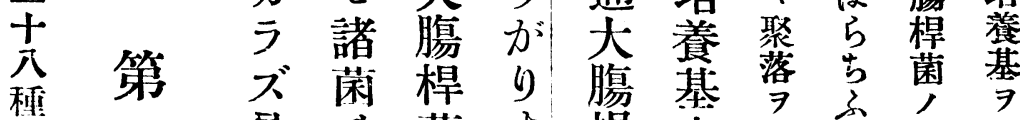

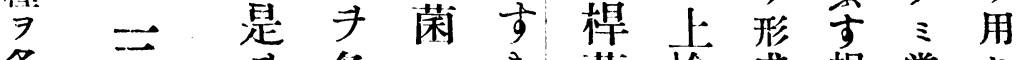
各西名公き藏檢成秙常七

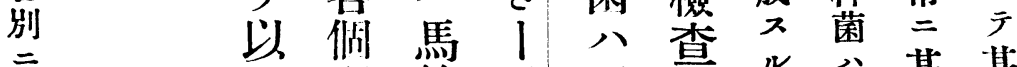
心

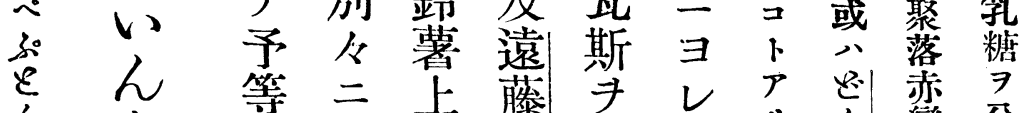

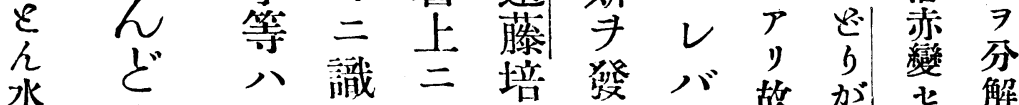
水 公膱二培留 心゙故加策解 二员 二

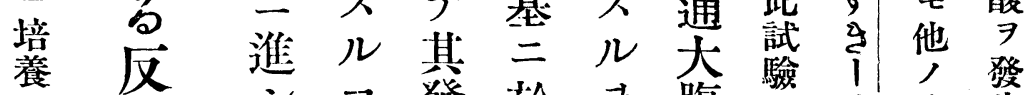
食シコ發於

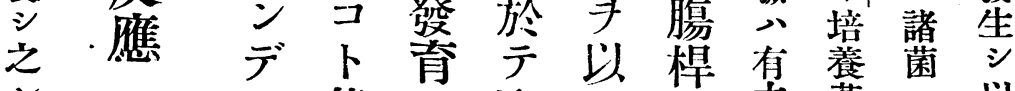
い能肘聚示菌力基分以

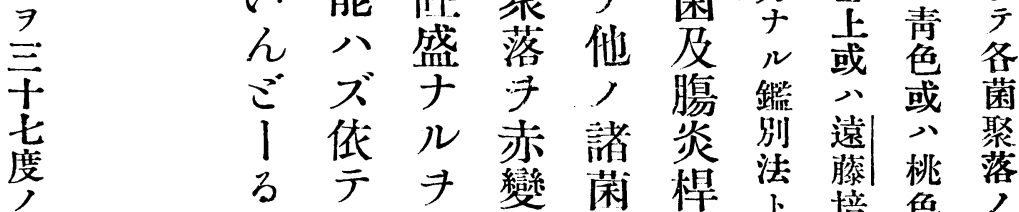

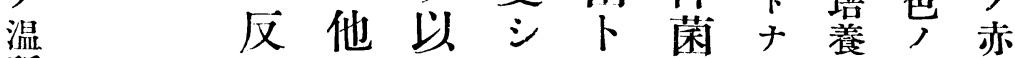

所

納

$x$

後

于

旨

間 應二テば區八ス基聚色 于 適 鑑 $ら$ 別牛 三上落

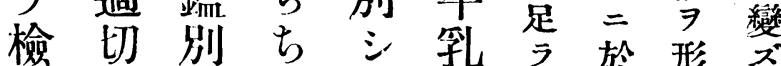
查ナ法ふ得 セル,す凝屡七中 少參柦盖風多否 法考时通 法考通

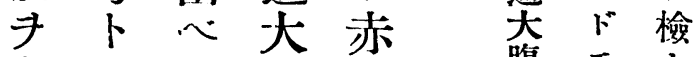
求子।膓痢腹モセ メル型桿桿菌赤 
（129）退郎四茎传帖及郎太福永吉
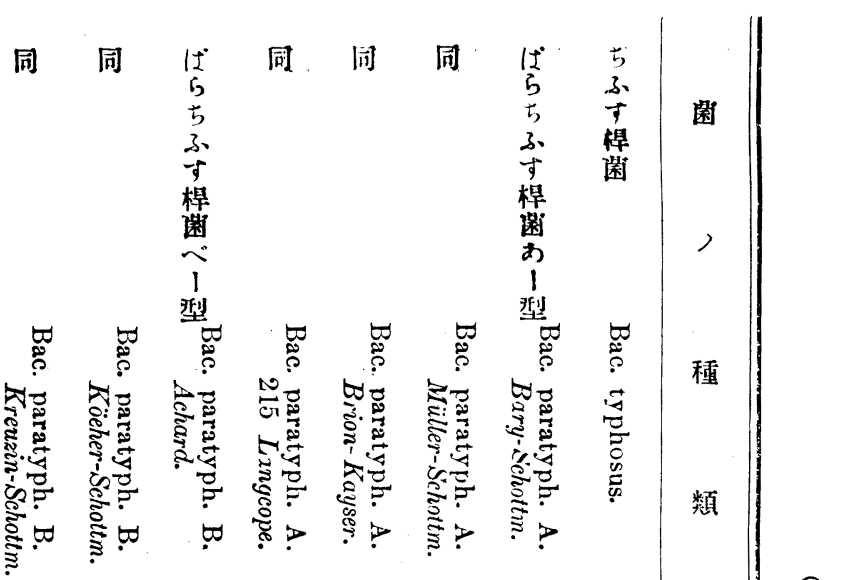

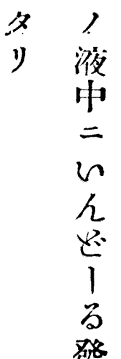

種 發

颣

直

焎

- - - - - $-1-$

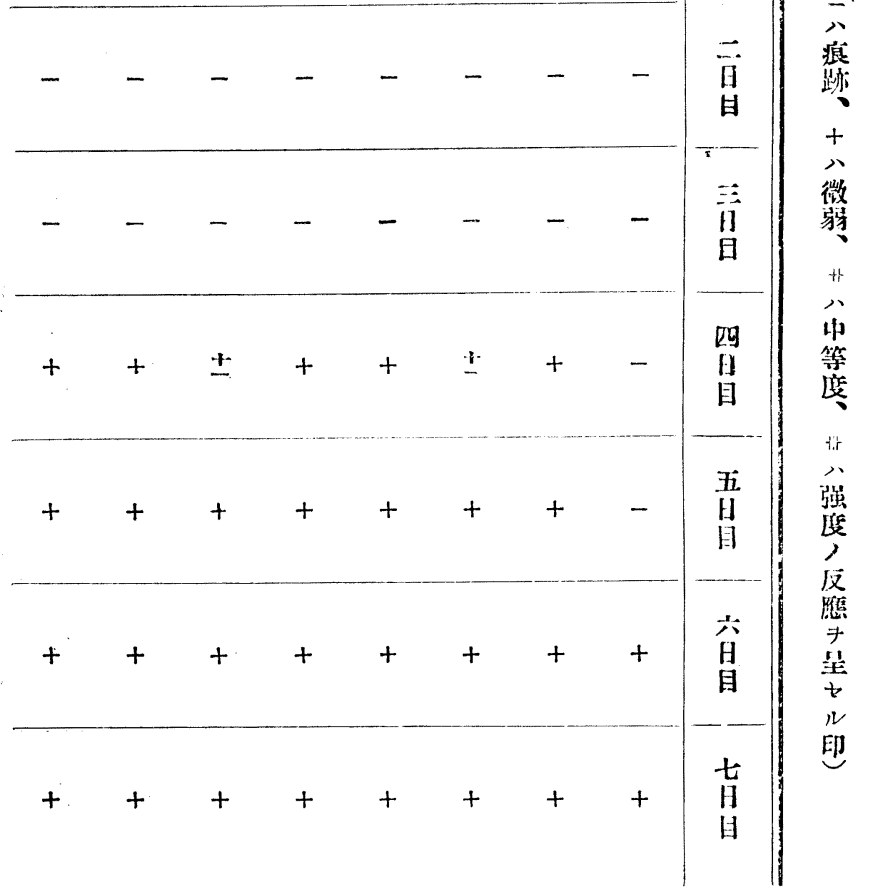$$
\text { 亞 }
$$$$
\text { 你 }
$$$$
\text { 酸 }
$$$$
\text { 加 }
$$$$
\text { 里 }
$$$$
\text { 硫 }
$$$$
\text { 訟 }
$$$$
\text { 用 }
$$$$
\text { 七 }
$$$$
\bar{\jmath}
$$$$
\text { 檢 }
$$$$
\text { 查 }
$$$$
\text { 七 }
$$$$
\text { 的 }
$$$$
=
$$$$
\text { 次 }
$$$$
\text { 表 }
$$$$
=
$$$$
\text { 示 }
$$$$
\text { x }
$$$$
\text { ガ }
$$$$
\text { 如 }
$$$$
\text { キ }
$$$$
\text { 成 }
$$$$
\text { 績 }
$$$$
\text { 马 }
$$$$
\text { 得 }
$$ 
同同同同同同同同同同

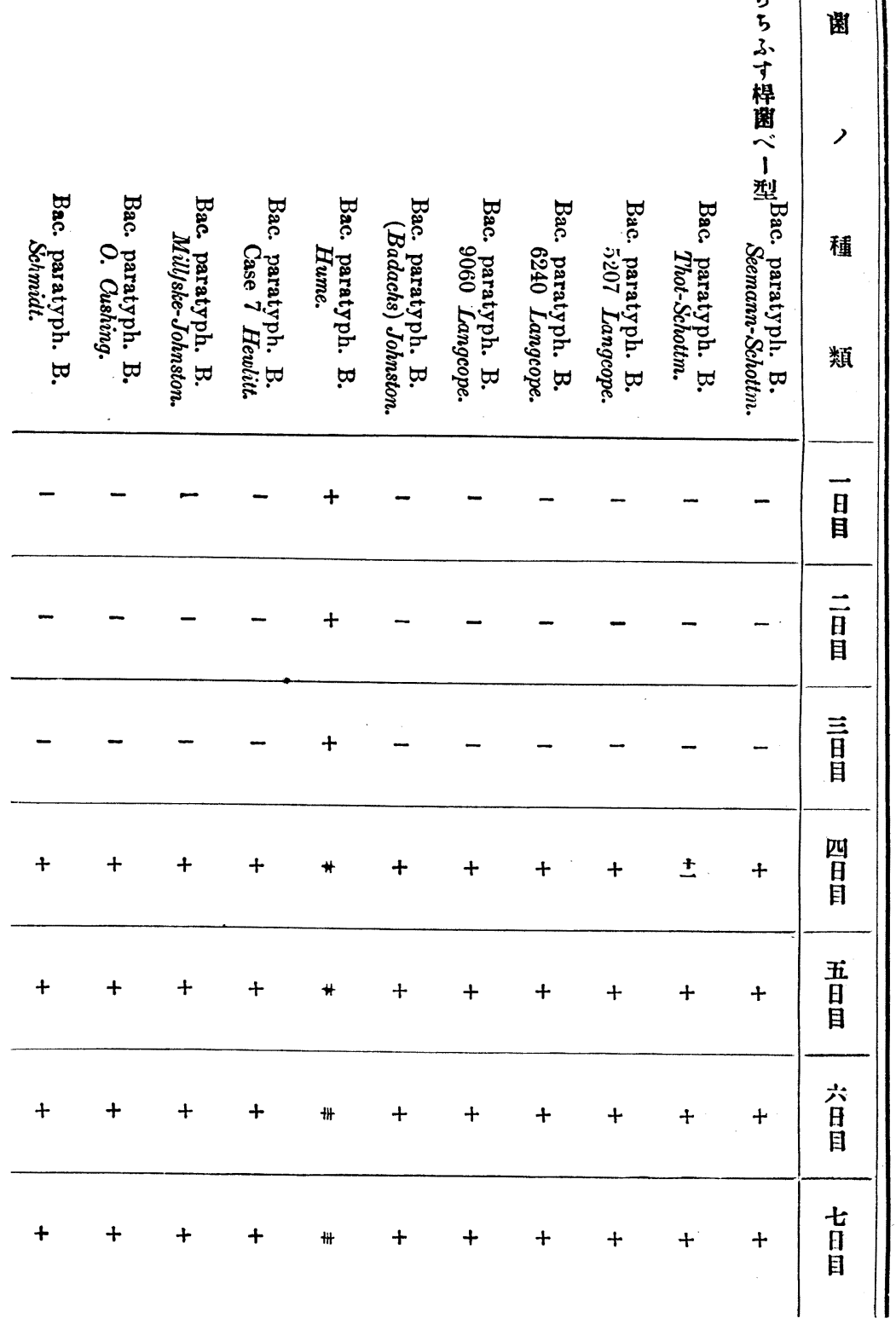


（131）述郎四堂佳帖及郎太福永吉

涌 及

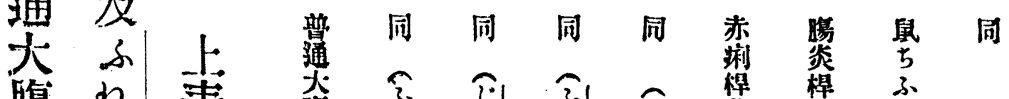

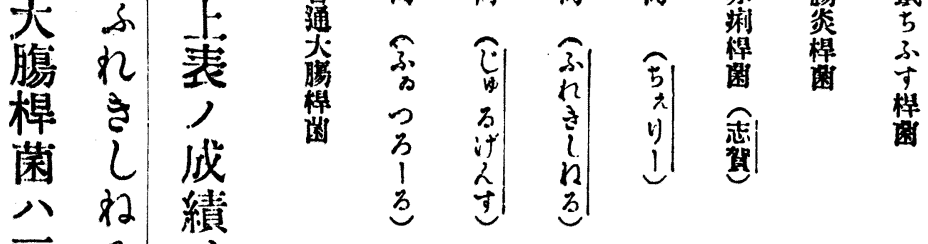

三る。

百赤通

自 痢 觀

二桿

引菌 ル

1 公

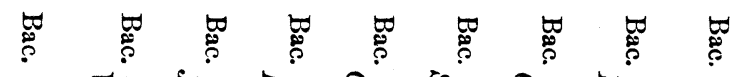

ถ

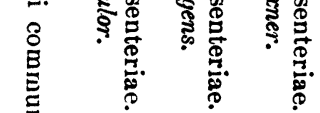

め最ふ

ばモ

ら迅 め

ち 速 ば

及 $=5$

$-\frac{1}{9}$ 具

桿

菌强蓑

尹 盛 桿

除二菌

キいへ

タ ん 1

ルご型

他 交

)

ば

万産り

万生 1

子 齐

于 次痢

桿 三 桿

菌普 菌 
用十各 7 井

如三立士一先夕含該

斯供方兰時等り水試

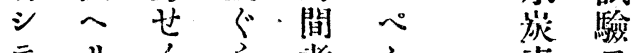

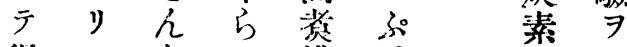

得 $ち$ む 洲 $\varepsilon$ 行

为め棌

ル 17 \%十

各元尖く

培 万後 ら

䆙宛别手さ

基 $\quad$ 今

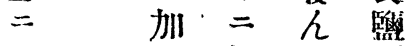

二 加に五

父 简

程 愬

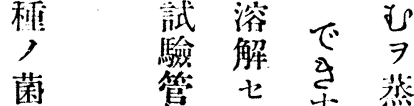

$\exists$

夫

尔

别

々

$=$

加

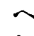

噼

簑

内

$=$

納

$x$

以

原

其

擘

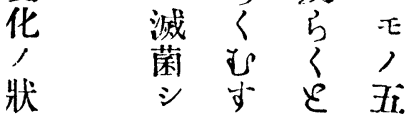

狀

態

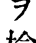

檢

查

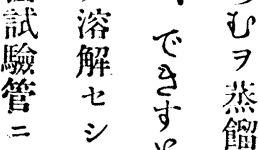

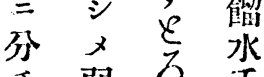

天弱 方

然 क ! 立

ルる せ 学

後かせ せ

三 $502 h$

十性 分

分卜万め

間 $シ 11$

败市市

蒸牥尚浴

氣 ら勧船

釜む।

$=$, 世夕

于 5 度

于 浴 1 組

試液也製

驗自垈

学各之
2 加芯
シ 第 当藏

二牙別系中

で盺冬高じ

等霹四 桿

争鑑菌

万等含識公代

念 沓最 ん

咕使沓儿紫卞

生等コ邀及

各素卜弓多

$k n=$ 亦六

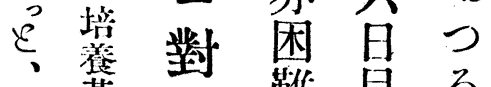

基入難自了

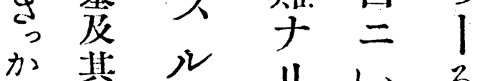

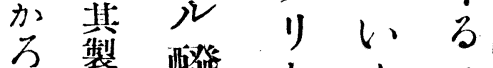

1 法撥登九,

也慈嚾云型

奖作 ᄀ I

如用心方四

纪, 新厚

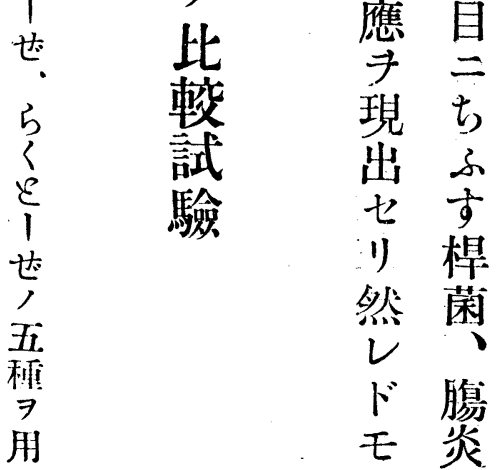




\begin{tabular}{|c|c|c|c|c|c|c|}
\hline$\zeta$ & $ま$ & ᄅ & ま & T゙ & 些水含 & \\
\hline く & 方 & $j$ & L & $\stackrel{+9}{\frac{1}{3}}$ & & \\
\hline 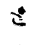 & そ & 万 & $に$ & $\stackrel{2}{2}$ & 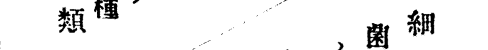 & \\
\hline 1 & 1 & 1 & つ & i & 類㮔 & \\
\hline ぜ & ぜ & ぜ & 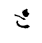 & ぜ & & \\
\hline- & + & - & + & + & Bac. typhosus. & \\
\hline- & + & - & + & + & Bac. paratyph. A. Bary-Schottm. & \\
\hline - & + & - & + & + & "Müller-Schottm. & \\
\hline - & + & - & + & + & "Brion-Kuysєr. & \\
\hline- & + & - & + & + & "215 Longcope. & \\
\hline- & + & - & + & + & B. Achard, & \\
\hline -- & + & - & + & + & $"$ Koeher-Schottm. & \\
\hline-- & + & $\cdots$ & + & + & "Kreukin-Schottm. & \\
\hline- & + & - & + & + & „Seemann-Schottm. & \\
\hline - & + & - & + & + & "Thot-Schottm. & \\
\hline- & + & - & + & + & " 5207 Langcope. & \\
\hline- & + & - & + & + & $" 6210 \quad "$ & \\
\hline - & + & - & + & + & " $9060 \quad "$ & \\
\hline - & + & - & + & + & " (Badachs) Johnston. & \\
\hline - & + & - & + & + & ", Case 7 Hexlitt. & \\
\hline - & + & - & + & + & "Hume. & \\
\hline - & + & - & + & + & "Mill/ske-Johnston. & \\
\hline- & + & - & + & + & "O. Cushing. & \\
\hline- & + & - & + & + & "Schmidt. & \\
\hline - & + & - & + & + & "W. Achard. & \\
\hline- & - & - & - & + & Bac. dysenteriae Shiga. & \\
\hline- & - & - & + & + & Celli. & \\
\hline - & - & + & + & + & Flexner. & \\
\hline$\tau$ & + & + & + & + & Jïrgens. & \\
\hline+ & + & + & + & + & Vitulor. & \\
\hline - & + & - & + & + & Bac. typhi murium Löffler. & \\
\hline- & + & - & + & + & $" \quad$ enteritidis Gärtner. & \\
\hline+ & + & - & + & + & $" \quad$ coli commune. & \\
\hline
\end{tabular}


常 二 郝

二 シ 频 予

諸 桿等

菌常菌 八

六 多 殊 先

十數志各

度少鿓

, 動菌二

溫物, 對

$\Rightarrow \quad$ 自六

一失働

時 7 性 复

間 .モ 免 疫

加 , 疫 血

へナハ清

于リ家 7

耗 是 兔 得

少 $\Rightarrow=$

タ 以 對 カ

ルテ シ 零

モ子于

人等 頗 各

小菌

使 此有 $\Rightarrow$

用等 毒 以

七,

リ損》家

而耗 故 鬼

到

晦 其 免

此少疾疼

泩 レ 業 七

射 $\Sigma \Rightarrow \quad$

齐 全

八雼 ᄀ

先 $又$ ス

叶 ル 然

皮免八尓

企疫極二

二試 $x$ 各

後 驗 テ 菌

于 二 困 就

静 八難中
リ鑑炎諸趣痢

別桿菌手桿上

法菌卜

卜八鑑異八三

于其別三其於

又作 的分

二用得少用儿

足同儿灭, 成

今 一下曾 狀 績

ズ二雖通態二

茲 シ F゙夫蒡

二テモ腸三リ

於毫ち桿他諸

テモふ菌, 菌

予區主王諸,

等別桿亦菌含

八ス菌特卜水

更儿、殊異炭

三コばノ三素

進卜 5 作 又

シ能ち用儿對

デ八ふき, ス

凝 ズす有

集故桿セナ作

反二菌少亏用

應此故 ズ

尹試鼠三該比

比驗 5 此菌較

較 モ 等種 觀

入亦宗, 相察

ルタ桿菌互 ス

二一菌八三ル

至般及他亦二

乙, 膓, 其赤 


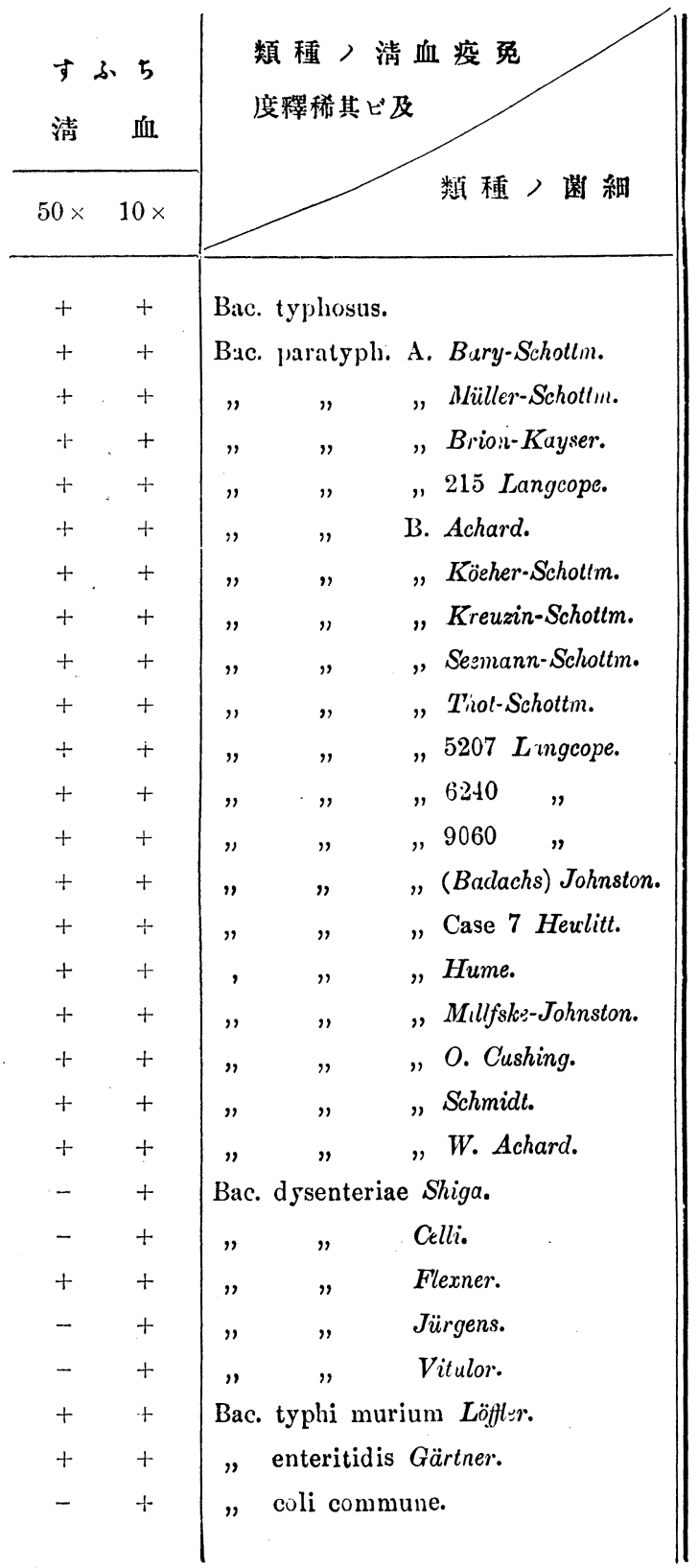

凝 二 等 脈

集辒 入内

辰入終 =

礁 $ル ニ$ 七

二凝 二H

優 集十,

㕅八間

モ 應 種 歇

, 7 , 7

$>$ 比菌以

几 較二亏

7 對 對 初

目照 ス

擊七儿牛

七シ 二白

り 二士金

令鼻公程

成强,

績 大 免 次

$\exists$ 于疫第

表心血 二

示 類 濯 增

七屬 7 量

心作

次應儿ッ

7 ᄀ

如呈 1 前

シ 7 後

为 得 五

，回

○取

ナ侬 覆

シ 洼

各射

類 色 7

屬疫ナ

度血 七

啱清 リ

ᄀ 斯

却以

广 $\bar{~}$

荋菌荣 


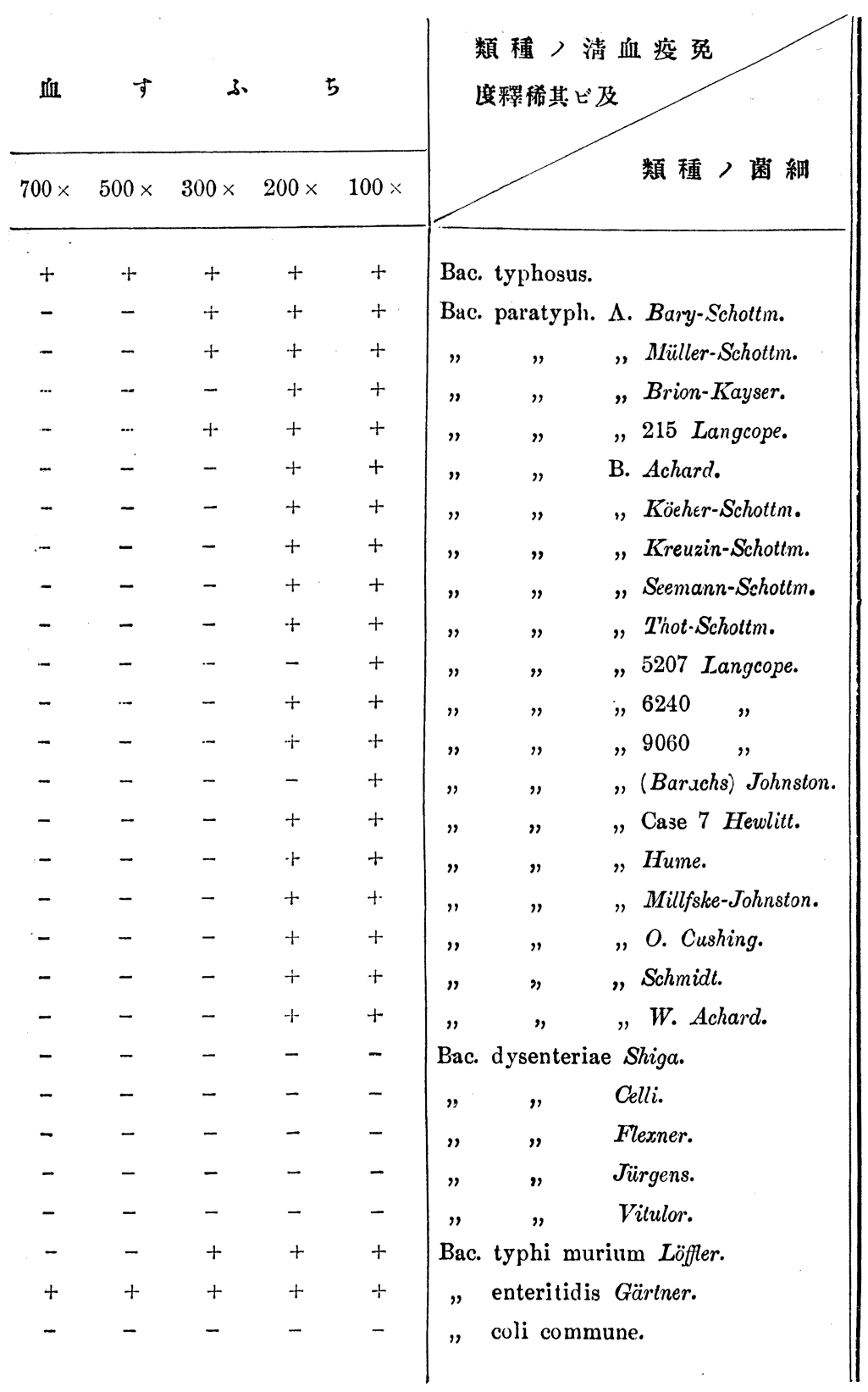


（137）䢑郎四崖佳帖及郎心福永吉

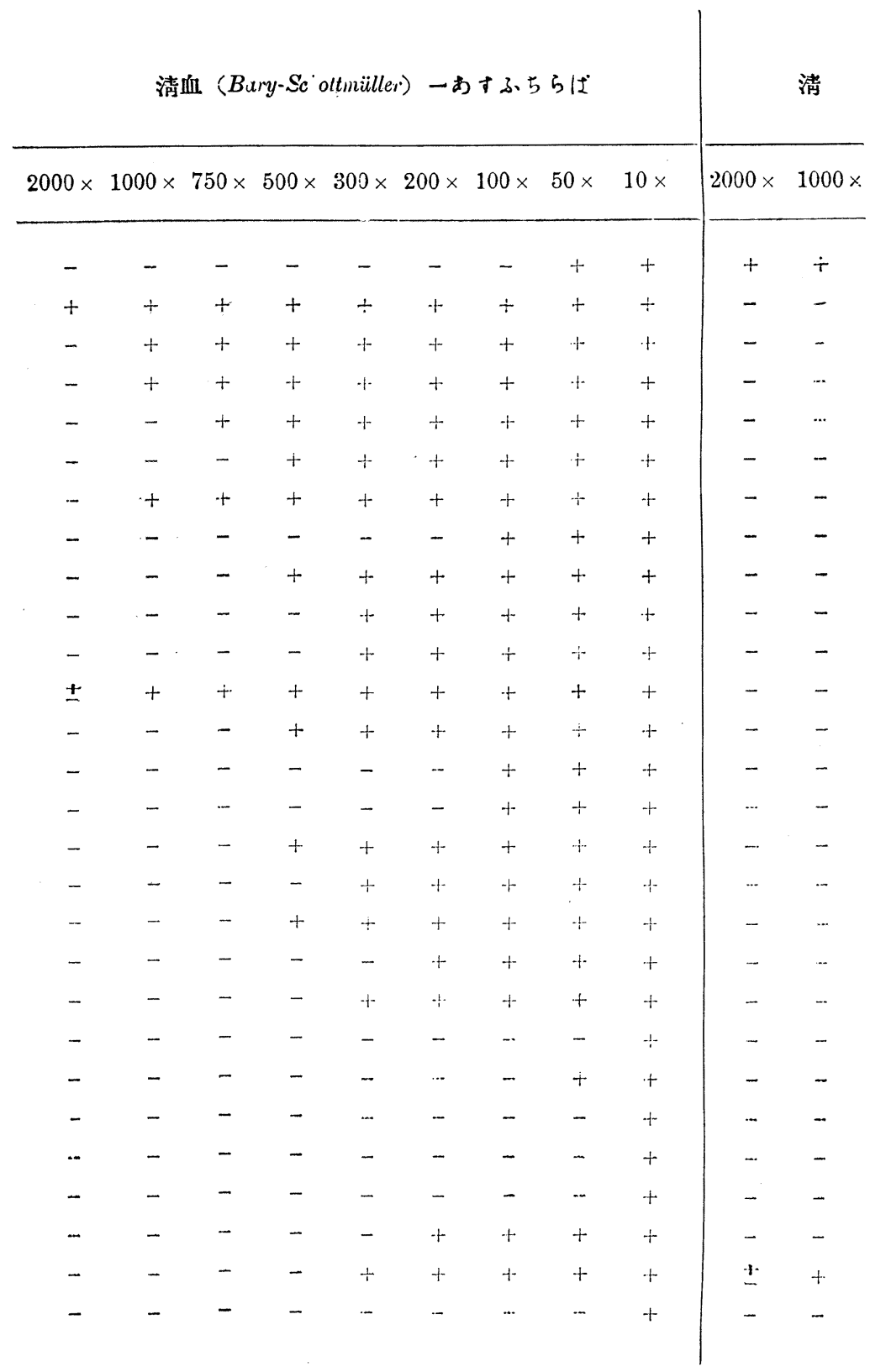




\begin{tabular}{|c|c|c|c|c|c|c|c|}
\hline \multicolumn{5}{|c|}{ Schotlmüller)ーむすふららば } & \multirow{2}{*}{\multicolumn{3}{|c|}{ 頑種 ノ清血疫免 }} \\
\hline $300 \times$ & $200 x$ & $100 \times$ & $50 x$ & $10 \times$ & & & \\
\hline- & - & - & + & + & Bac. & typhosus. & \\
\hline+ & + & + & + & + & Bac. & paratyph. A & Bary-Schottm. \\
\hline+ & + & + & + & + & $"$ &,,$\quad$, & Müller-Schottm. \\
\hline$\dot{1}$ & + & + & + & + & $"$ & & Brion-Kayser. \\
\hline+ & + & + & + & + & $"$ & $"$ & 215 Langcope. \\
\hline t- & + & + & + & + & $"$ & , & Achard. \\
\hline+ & + & + & + & + & $"$ & $"$ & Köeher-Schottm. \\
\hline+ & + & + & + & + & $"$ & $"$ & Kreuzin-Schottm. \\
\hline 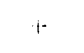 & + & + & + & + & $"$ & $"$ & Seemann-Schottm. \\
\hline+ & + & + & + & + & $"$ & $"$ & Thot-Schottm. \\
\hline 1 & + & + & + & + & $"$ & $"$ & 5297 Langcope. \\
\hline+ & + & + & + & + & $"$ & $"$ & $6210 \quad "$ \\
\hline+ & + & + & + & + & , & $"$ & $9060 \quad$, \\
\hline+ & + & + & + & + & $"$ & $"$ & , (Badachs) Johnston. \\
\hline+ & + & + & + & + & $"$ & $"$ & Case 7 Hewlitt. \\
\hline$\cdots$ & $\psi$ & + & + & + & $"$ & $"$ & Hume. \\
\hline- & + & + & + & + & $"$ & " & , Millfske-Johnston. \\
\hline 4. & + & + & + & + & $"$ & $"$ & O. Cushing. \\
\hline- & + & + & + & + & ", & & Schmidt. \\
\hline$\div$ & + & + & + & + & $"$ & & , W. Achard. \\
\hline - & - & - & - & + & Bac. & dysenteriae & Shiga. \\
\hline$\cdots$ & - & - & + & + & $"$ & , & Celli. \\
\hline - & - & - & - & + & .. & $"$ & Flexner. \\
\hline- & - & - & - & + & ,. & $"$ & Jürgens. \\
\hline - & - & - & - & + & $"$ & " & Vitulor. \\
\hline$\cdots$ & + & + & $t$ & + & Bac & typhi. muri & ium Löffler. \\
\hline - & + & + & + & + & & enteritidis & Gärtner. \\
\hline- & $\ldots$ & - & - & + & , & coli commur & ine. \\
\hline
\end{tabular}


（139）拈郎四坴佳帖及郎太福永吉

\begin{tabular}{|c|c|c|c|c|c|c|c|c|c|c|}
\hline \multicolumn{4}{|c|}{ 清 血 (Brion-Kuyser) } & \multicolumn{3}{|c|}{ 一あすふちらば } & \multicolumn{4}{|c|}{ 声 血 (Müller } \\
\hline $750 \times$ & $500 x$ & $300 x$ & $200 x$ & $100 \times$ & $50 x$ & $10 x$ & $2000 x$ & $1000 x$ & $570 \times$ & $500 x$ \\
\hline- & - & - & - & - & + & + & - & -- & - & $\ldots$ \\
\hline+ & + & + & + & + & + & + & - & + & + & + \\
\hline+ & + & + & + & + & + & + & + & + & + & + \\
\hline+ & + & + & + & + & + & + & - & + & + & + \\
\hline+ & + & + & + & + & + & + & - & + & + & + \\
\hline- & - & - & + & + & + & + & - & - & - & + \\
\hline- & - & + & + & + & + & + & - & - & - & + \\
\hline- & - & + & + & + & + & + & - & - & - & - \\
\hline- & + & + & + & + & + & + & - & + & + & + \\
\hline- & - & - & + & + & $+\cdot$ & + & - & - & - & + \\
\hline+ & + & + & + & + & $t$ & + & - & - & - & + \\
\hline - & - & - & + & + & + & + & + & + & + & + \\
\hline- & + & + & + & + & + & + & - & + & + & + \\
\hline- & - & - & + & + & + & + & - & - & - & + \\
\hline- & - & - & + & + & + & + & - & - & - & + \\
\hline+ & + & + & + & + & + & + & - & $\ldots$ & - & - \\
\hline- & + & + & + & + & + & + & - & - & - & - \\
\hline- & - & - & + & + & + & + & - & - & + & + \\
\hline- & - & - & - & $\cdots$ & - & + & - & - & - & - \\
\hline+ & + & + & + & + & + & + & -- & - & - & + \\
\hline- & -- & - & - & - & - & + & - & - & - & - \\
\hline- & - & - & - & - & - & + & - & - & - & - \\
\hline- & - & - & - & - & + & + & - & - & - & - \\
\hline- & - & - & - & - & - & + & - & - & - & - \\
\hline$\ldots$ & - & - & - & - & + & + & - & - & - & - \\
\hline- & - & - & + & + & + & $t$ & - & - & - & - \\
\hline- & - & - & - & + & + & + & - & - & - & - \\
\hline- & - & - & - & - & - & + & - & - & - & - \\
\hline
\end{tabular}




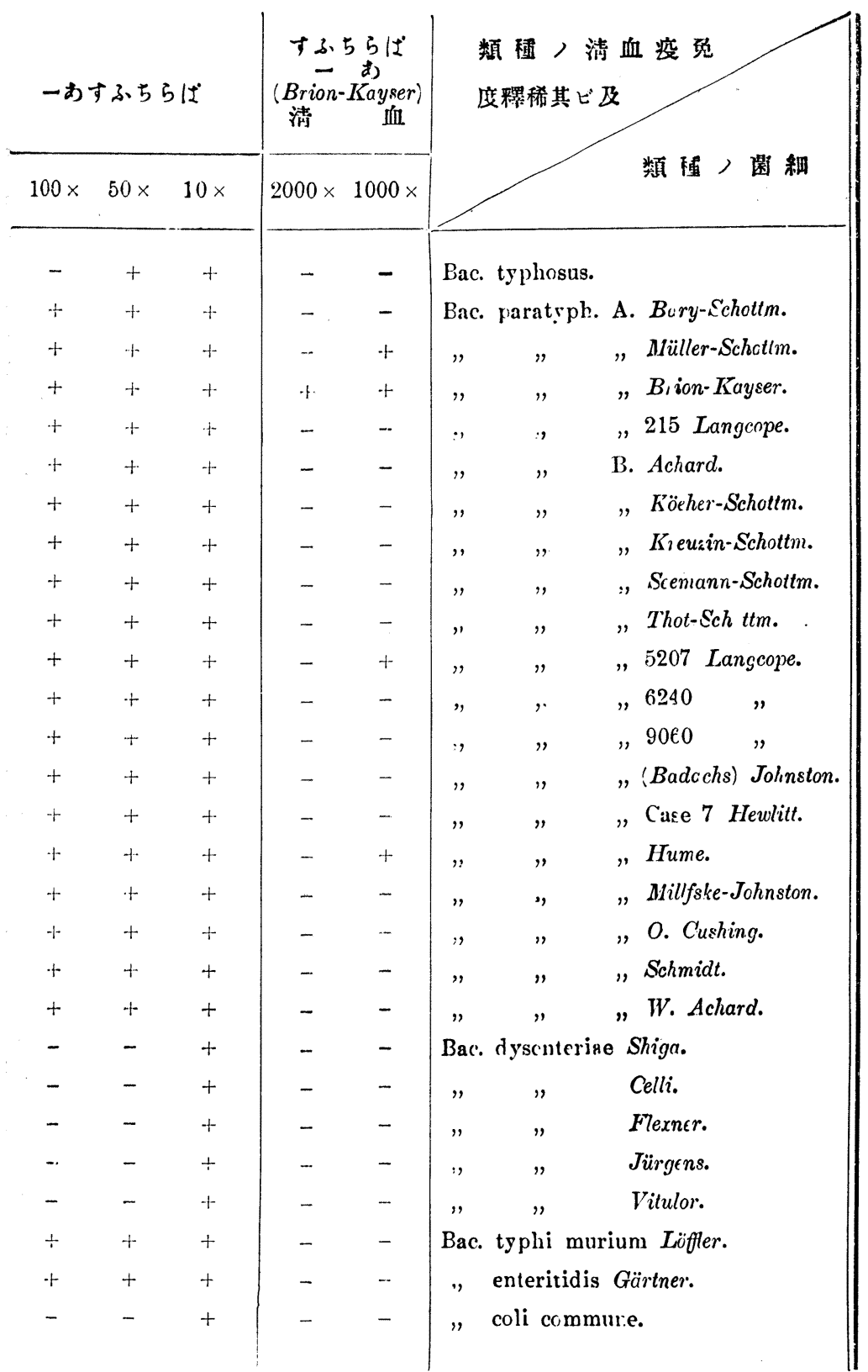


（141）述郎四彥佳帖及郎太福永吉

\begin{tabular}{|c|c|c|c|c|c|c|c|c|c|c|}
\hline \multicolumn{5}{|c|}{ 湔血 (Achard) 一へするちらば } & \multicolumn{2}{|r|}{ 清 } & 血 & $(215$ & \multicolumn{2}{|c|}{ Langcope } \\
\hline $300 \times$ & $200 x$ & $100 \times$ & $50 x$ & $10 x$ & $2000 \times$ & $1000 \times$ & $750 \times$ & $500 x$ & $300 \times$ & $200 x$ \\
\hline- & - & -- & + & + & - & - & - & - & - & - \\
\hline+ & + & + & + & + & - & $+t$ & + & + & + & + \\
\hline+ & + & $\div$ & + & + & - & + & + & + & + & + \\
\hline+ & + & + & + & + & - & - & + & + & + & + \\
\hline+ & + & + & + & + & + & + & + & + & + & + \\
\hline+ & + & + & + & + & - & - & - & 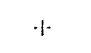 & + & + \\
\hline+ & + & + & + & + & - & - & - & - & + & + \\
\hline+ & + & + & + & + & - & - & + & + & + & + \\
\hline+ & + & + & + & + & - & - & - & + & + & + \\
\hline+ & $\div$ & + & + & + & - & - & - & - & - & + \\
\hline+ & + & + & + & + & - & - & - & - & + & + \\
\hline+ & + & + & + & + & - & - & - & - & + & + \\
\hline+ & + & + & + & + & - & - & - & - & + & + \\
\hline+ & + & + & + & + & - & - & - & - & + & + \\
\hline+ & + & + & $\div$ & + & - & + & + & $t$ & + & + \\
\hline+ & + & + & $\div$ & + & - & - & - & + & + & + \\
\hline+ & + & + & + & + & - & - & - & - & - & + \\
\hline+ & + & + & + & + & - & - & - & - & + & + \\
\hline+ & + & + & + & + & - & - & - & - & $\div$ & + \\
\hline+ & + & + & + & + & - & $\cdots$ & + & $\div$ & + & + \\
\hline- & - & - & - & + & - & - & - & - & - & - \\
\hline- & - & - & - & + & - & - & - & - & - & - \\
\hline- & - & - & - & + & - & - & - & - & $\therefore$ & - \\
\hline- & - & - & - & + & - & - & - & - & - & - \\
\hline- & - & - & - & + & $\ldots$ & - & $\ldots$ & - & - & -. \\
\hline+ & + & + & + & + & - & - & - & - & + & + \\
\hline+ & + & + & + & + & - & - & $\ldots$ & - & - & + \\
\hline- & - & + & + & + & - & - & - & - & - & - \\
\hline
\end{tabular}




\begin{tabular}{|c|c|c|c|c|c|c|c|}
\hline \multirow[b]{2}{*}{$10 x$} & \multicolumn{4}{|c|}{ 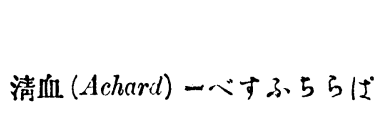 } & \multicolumn{3}{|c|}{$\begin{array}{l}\text { 類種 ノ清血疫免 } \\
\text { 度釋稀其ビ及 }\end{array}$} \\
\hline & 2000 & 000 & $50 \times$ & $500 \times$ & \\
\hline+ & -- & - & - & - & \multicolumn{3}{|c|}{ Bac. typhosus. } \\
\hline+ & - & $\ldots$ & - & + & \multicolumn{3}{|c|}{ Bac. paratyph. A. Bary-Schottm. } \\
\hline+ & - & - & - & - & \multicolumn{3}{|c|}{,$\quad ;, \quad, ;$ Müller-Schottm. } \\
\hline+ & - & - & - & - & \multicolumn{3}{|c|}{$" \quad, \quad "$ Brion-Kayser. } \\
\hline+ & - & - & + & + & \multicolumn{3}{|c|}{$" \quad \quad \quad \quad, 215^{\prime}$ Langcope. } \\
\hline+ & + & + & + & + & \multicolumn{3}{|r|}{ B. Achard. } \\
\hline+ & - & + & + & + & \multicolumn{3}{|c|}{$" \quad, \quad$ "Köeher-Sehottm } \\
\hline+ & - & - & + & + & \multicolumn{3}{|c|}{$" \quad, \quad$, Kreuzin-Schottm. } \\
\hline+ & - & - & + & + & \multicolumn{3}{|r|}{ "Seemann-Schottm. } \\
\hline+ & - & - & + & + & \multicolumn{3}{|r|}{ "Thot-Schottm. } \\
\hline+ & - & - & + & + & \multicolumn{3}{|r|}{, 5297 Langcope. } \\
\hline+ & + & + & + & + & $"$ & \multicolumn{2}{|r|}{, $6240 \quad "$} \\
\hline+ & - & - & - & + & $"$ & \multicolumn{2}{|r|}{$" 9060 \quad "$} \\
\hline+ & - & - & + & + & , & $"$ & ", (Badachs) Johnston. \\
\hline+ & $\cdots$ & - & - & + & $"$ & " & "Case 7 Hewlitt. \\
\hline+ & $\cdots$ & + & + & + & $"$ & $"$ & ¿Hume. \\
\hline+ & - & $\cdots$ & + & + & 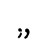 & $"$ & "Millsfke-Johnston. \\
\hline+ & - & - & + & + & $"$ & $"$ & " O. Cushing. \\
\hline+ & - & - & + & + & $"$ & $"$ & "Schmidt. \\
\hline+ & - & - & - & + & $"$ & , & "W. Achard. \\
\hline+ & - & - & - & - & Bac. & dysen & ae Shiga. \\
\hline+ & - & - & - & - & $"$ & " & Celli. \\
\hline+ & - & $\ldots$ & - & - & $"$ & $"$ & Flexner. \\
\hline+ & $\ldots$ & - & $\ldots$ & - & $"$ & $"$ & Jïrgens. \\
\hline+ & $\ldots$ & - & - & - & $"$ & " & Vitulor. \\
\hline$\%$ & - & - & + & + & Pac. & typhi & arium Löffler. \\
\hline+ & - & - & - & + & & enteri & s Gärtner. \\
\hline+ & - & - & - & - & & coli c & nune. \\
\hline
\end{tabular}




\begin{tabular}{|c|c|c|c|c|c|c|c|c|c|c|}
\hline \multicolumn{3}{|c|}{$\begin{array}{c}\text { ーべすふららば } \\
(215 \text { Langcope) } \\
\text { 清 血 }\end{array}$} & \multicolumn{5}{|c|}{ (Brimn-Kayser) } & \multicolumn{3}{|c|}{ 一ツすふちらば } \\
\hline $100 \times$ & $50 \times$ & $10 \times$ & $2000 x$ & $1000 \times$ & $750 \times$ & $500 \times$ & $300 \times$ & $200 \times$ & $100 x$ & $50 x$ \\
\hline- & $\div$ & + & - & - & - & - & - & - & + & + \\
\hline- & + & + & - & - & - & + & + & + & + & + \\
\hline$\div$ & $\dot{\tau}$ & + & - & - & - & - & + & + & + & + \\
\hline+ & + & + & - & - & - & $\cdots$ & + & + & + & + \\
\hline+ & + & + & - & - & - & - & + & + & + & + \\
\hline+ & + & + & - & - & - & - & + & + & + & + \\
\hline+ & + & + & - & + & + & + & + & + & + & + \\
\hline+ & + & $t$ & - & - & - & + & + & + & + & + \\
\hline+ & + & + & - & - & - & + & + & + & + & + \\
\hline+ & + & + & - & - & - & - & + & + & + & + \\
\hline+ & + & + & - & - & $t$ & + & + & + & + & + \\
\hline+ & + & + & - & - & - & - & + & + & + & + \\
\hline+ & + & + & - & - & - & - & + & + & + & + \\
\hline+ & + & + & - & - & - & - & + & + & + & + \\
\hline+ & + & + & + & + & + & + & + & + & + & + \\
\hline+ & + & + & - & - & - & - & + & + & $\therefore$ & + \\
\hline+ & + & + & - & - & - & - & + & + & + & + \\
\hline$r$ & + & + & - & $\ldots$ & - & + & + & + & + & + \\
\hline+ & + & + & - & - & - & + & + & + & + & + \\
\hline+ & + & + & - & - & $+\cdot$ & + & + & + & + & + \\
\hline$\ldots$ & - & + & $\ldots$ & - & - & - & - & - & - & - \\
\hline$\ldots$ & - & + & - & - & - & - & - & - & - & - \\
\hline$\cdots$ & $\cdots$ & $t$ & $-\cdot$ & - & - & - & - & - & - & - \\
\hline- & - & + & - & - & - & - & - & - & - & + \\
\hline$\ldots$ & - & + & $\cdots$ & - & $\ldots$ & - & - & - & - & - \\
\hline$\because$ & + & + & - & $t$ & + & + & + & + & + & + \\
\hline+ & + & + & - & - & + & + & + & + & + & + \\
\hline$\cdots$ & + & + & - & - & - & - & - & - & + & + \\
\hline
\end{tabular}


血（215 Langcope）ーべすふらら゙

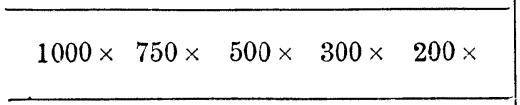

類種 ノ清血疫免 度釋稀其ビ及

類種 つ闲細
Bac. ty ! hosus.

Bac. paratypì. A. Bary-Schottm.

" " , Müller-Schottm.

" " "Brion-Kayser.

" " " 215 Langcope.

, , B. $A$ hard.

, , "Köeher-Schottm.

" " Kreuzin-Schottm.

" " , Siemann-Schotlm.

, " , Thot-Schottm.

" . . . 5297 Langcope.

" , " $6240 \quad$ "

" " "9060 "

$" \quad$,

" (Badachs) Johnston.

" Case 7 Hewlitt.

", IIume.

„Millske-Jolnston.

, O. Cushing.

, Schmidt.

,W. Achard.

Bac. dysenteriae Shiga.

$\begin{array}{lll}", & " & \text { Celli. } \\ " & " & \text { Flexner. } \\ " & " & \text { ürgens. } \\ , & " & \text { Vitulor. }\end{array}$

Bac. typhi. murium Löfler.

" enteritidis Gäıtner.

, coli commune. 


\begin{tabular}{|c|c|c|c|c|c|c|c|c|c|c|}
\hline $10 \times$ & $2000 x$ & $1000 \times$ & $750 \times$ & $500 \times$ & $300 x$ & $200 x$ & $100 \times$ & $50 \times$ & $10 \times$ & $2000 x$ \\
\hline+ & - & - & - & - & - & - & + & + & + & - \\
\hline+ & - & - & - & - & - & + & + & + & + & - \\
\hline+ & - & - & - & + & + & + & + & + & + & - \\
\hline+ & - & - & - & - & + & + & + & + & + & - \\
\hline+ & - & - & - & - & - & - & + & + & + & - \\
\hline+ & - & - & - & - & + & + & + & + & + & - \\
\hline+ & - & - & - & - & + & + & + & + & + & - \\
\hline+ & - & - & - & - & + & + & + & + & + & + \\
\hline+ & + & + & + & + & + & + & + & + & + & - \\
\hline+ & - & - & - & + & + & + & + & + & + & - \\
\hline+ & - & - & - & + & + & + & + & + & + & - \\
\hline+ & - & + & + & + & + & + & + & + & + & - \\
\hline+ & - & - & + & + & + & + & + & + & + & - \\
\hline+ & - & - & + & + & + & + & + & + & + & - \\
\hline+ & - & - & - & + & + & + & + & + & + & - \\
\hline+ & - & + & + & + & + & + & + & + & + & - \\
\hline+ & - & - & - & - & + & + & + & + & + & - \\
\hline+ & - & - & - & + & + & + & + & + & + & - \\
\hline+ & - & - & - & - & + & + & + & + & + & - \\
\hline+ & - & - & - & - & + & + & + & + & + & - \\
\hline+ & - & - & - & - & - & $\dot{-}$ & - & - & + & - \\
\hline+ & - & - & - & - & - & - & - & + & + & - \\
\hline+ & - & - & - & - & - & - & - & - & + & - \\
\hline+ & - & - & - & - & - & - & - & - & + & - \\
\hline+ & - & - & - & - & - & - & - & - & + & - \\
\hline+ & - & + & + & + & + & + & + & + & + & - \\
\hline+ & - & + & + & + & + & + & + & + & + & - \\
\hline+ & - & - & - & - & - & - & + & + & + & - \\
\hline
\end{tabular}




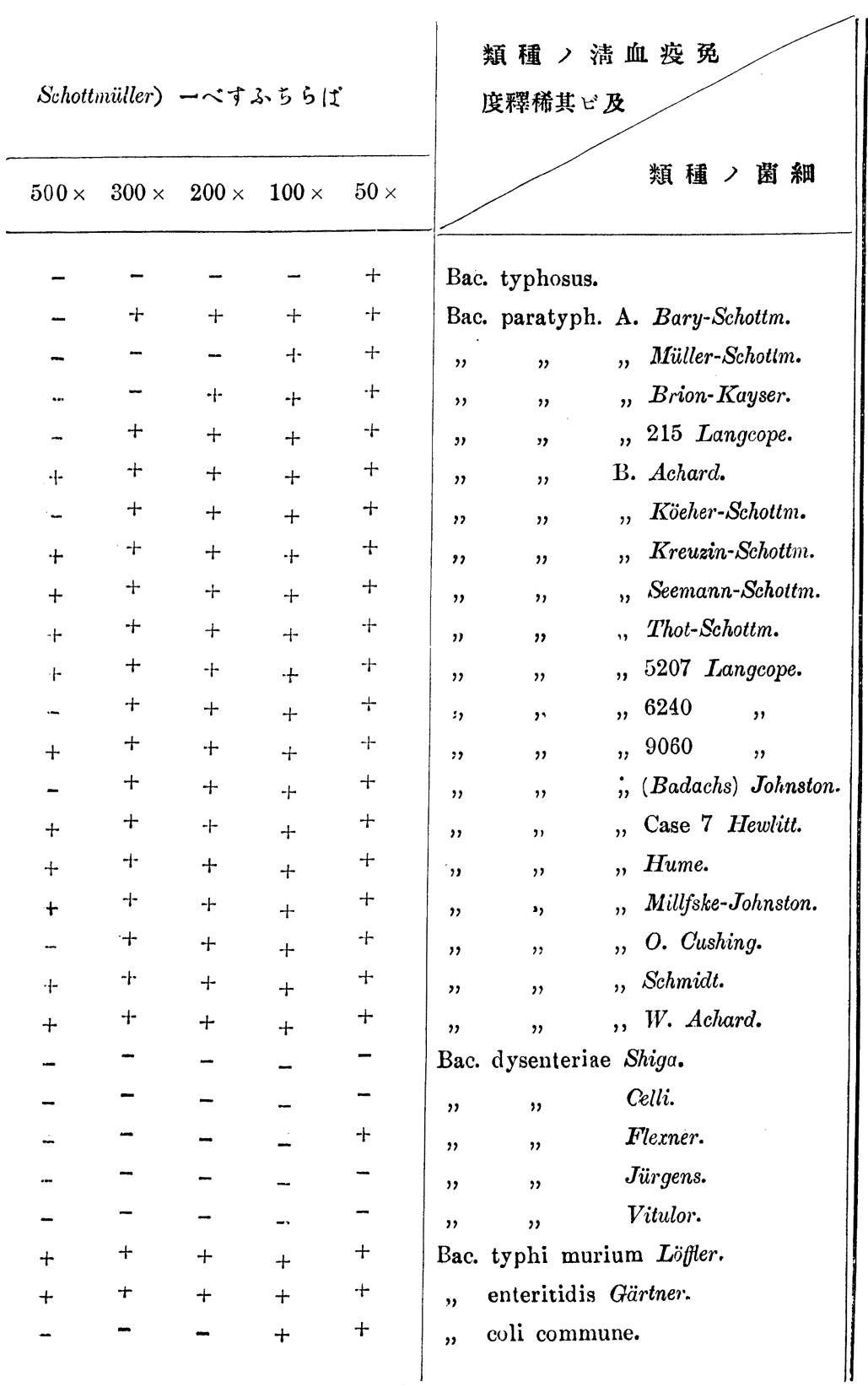




\begin{tabular}{|c|c|c|c|c|c|c|c|c|c|c|}
\hline \multicolumn{8}{|c|}{ 清 血 (5207 Langcope) 一ベすふちらば } & \multicolumn{3}{|c|}{ 清 血 ( $(T h o t$} \\
\hline $1000 \times$ & $750 \times$ & $500 \times$ & $300 \times$ & $200 \times$ & $100 \times$ & $50 \times$ & $10 \times$ & $2000 \times$ & $1000 \times$ & $750 \times$ \\
\hline- & - & - & - & - & - & + & + & - & - & - \\
\hline- & - & - & + & + & + & + & + & - & - & - \\
\hline- & - & - & - & - & + & + & + & - & - & - \\
\hline- & - & - & + & + & + & + & + & - & - & - \\
\hline- & - & + & + & + & + & + & + & - & $\ldots$ & - \\
\hline- & - & + & + & + & + & + & + & - & - & + \\
\hline- & - & - & + & + & + & + & + & - & - & - \\
\hline- & + & + & + & + & + & + & + & - & + & + \\
\hline- & - & - & + & + & + & + & + & - & - & + \\
\hline- & - & + & + & 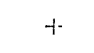 & + & + & + & + & + & + \\
\hline+ & + & + & + & + & + & + & + & - & - & + \\
\hline- & + & + & + & + & + & + & + & - & $\ldots$ & - \\
\hline$\ldots$ & - & + & + & + & + & + & + & - & - & - \\
\hline$\ldots$ & -. & + & + & + & + & + & + & - & - & - \\
\hline$\ldots$ & $\ldots$ & $\cdots$ & + & + & + & + & + & - & - & + \\
\hline$\ldots$ & $\ldots$ & $\cdots$ & + & + & + & + & + & - & - & - \\
\hline$\ldots$ & - & - & + & + & + & + & + & + & + & + \\
\hline$\ldots$ & - & + & + & + & + & + & + & - & - & - \\
\hline- & - & - & + & + & + & + & + & - & - & - \\
\hline- & + & + & + & + & + & + & + & - & - & + \\
\hline- & - & -. & $\ldots$ & - & - & - & + & - & - & - \\
\hline- & $\ldots$ & -. & - & - & - & - & + & - & - & - \\
\hline- & $\ldots$ & $\ldots$ & $\ldots$ & - & $\ldots$ & + & + & - & - & - \\
\hline- & $\ldots$ & $\ldots$ & - & - & $\ldots$ & $\cdots$ & + & - & - & $\cdots$ \\
\hline$\ldots$ & $\ldots$ & $\ldots$ & $\ldots$ & -- & -- & $\cdots$ & + & - & - & $\ldots$ \\
\hline- & $\ldots$ & - & + & + & + & + & + & -- & - & - \\
\hline$\ldots$ & - & + & + & + & + & + & + & - & - & + \\
\hline- & - & - & - & - & - & + & + & -- & - & - \\
\hline
\end{tabular}




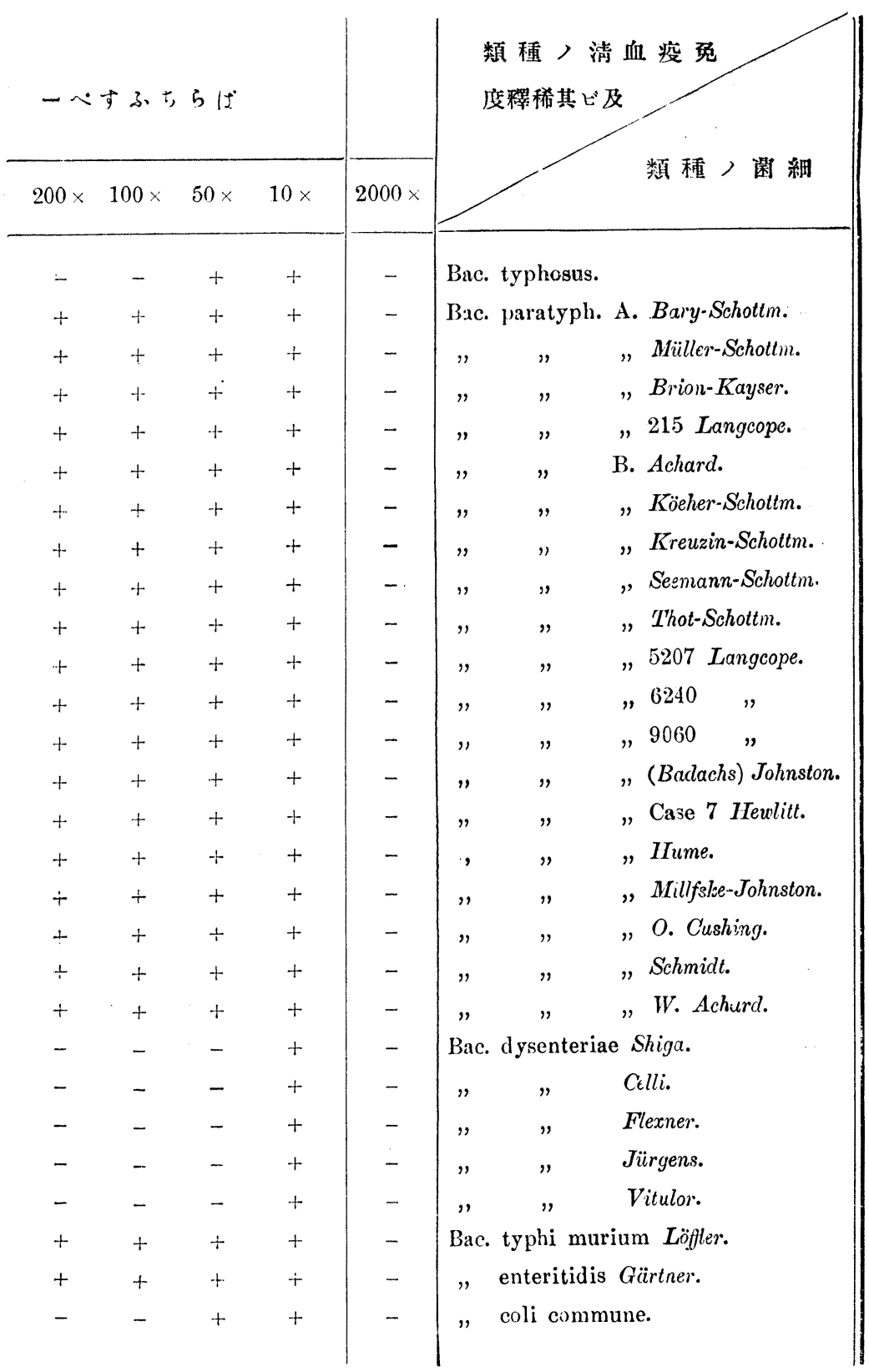


（149）拈郎四崖侉帖及郎太福永吉

\begin{tabular}{|c|c|c|c|c|c|c|c|c|c|c|}
\hline \multicolumn{2}{|c|}{ 清血 (9060 } & \multicolumn{4}{|c|}{ Langcope) 一べすふららば } & \multicolumn{5}{|c|}{ 声 血. (6240 Langcope) } \\
\hline $500 \times$ & $300 \times$ & $200 \times$ & $100 \times$ & $50 \times$ & $10 \times$ & $2000 \times$ & $1000 \times$ & $750 x$ & $500 \times$ & $300 x$ \\
\hline- & - & - & - & - & + & - & - & - & - & - \\
\hline$\ldots$ & - & $t$ & + & + & + & - & - & - & - & + \\
\hline$\ldots$ & + & + & + & + & + & - & - & - & - & - \\
\hline- & + & + & + & + & + & - & - & -- & - & + \\
\hline- & - & + & + & + & + & - & - & - & - & - \\
\hline+ & + & + & + & + & + & - & - & - & - & + \\
\hline+ & + & + & + & + & + & - & - & - & - & + \\
\hline+ & + & + & + & + & + & - & - & + & + & + \\
\hline+ & + & + & + & + & + & - & - & - & - & + \\
\hline+ & + & + & + & + & + & - & + & + & + & + \\
\hline+ & + & + & + & + & + & - & - & - & - & + \\
\hline+ & + & + & + & + & + & + & + & + & + & + \\
\hline+ & + & + & + & + & + & - & - & - & - & + \\
\hline+ & + & + & + & + & + & - & - & - & + & + \\
\hline+ & + & + & + & + & + & - & - & + & + & + \\
\hline+ & + & + & + & + & + & - & - & - & $-\cdots$ & + \\
\hline+ & + & + & + & + & + & - & -- & - & + & + \\
\hline+ & + & + & + & + & + & - & $\ldots$ & - & - & + \\
\hline+ & + & + & + & + & + & - & + & + & + & + \\
\hline+ & + & + & + & + & + & -- & - & + & + & + \\
\hline- & - & $\cdots$ & - & - & + & - & - & - & - & -- \\
\hline- & - & - & - & - & + & - & - & - & - & - \\
\hline- & - & - & - & - & + & - & - & - & - & - \\
\hline- & - & - & - & - & + & - & - & - & - & - \\
\hline- & - & - & - & - & + & - & - & - & - & - \\
\hline+ & + & + & + & + & + & - & - & - & + & + \\
\hline+ & + & + & + & + & + & - & - & - & - & + \\
\hline- & $\ldots$ & - & - & + & + & - & - & - & - & - \\
\hline
\end{tabular}




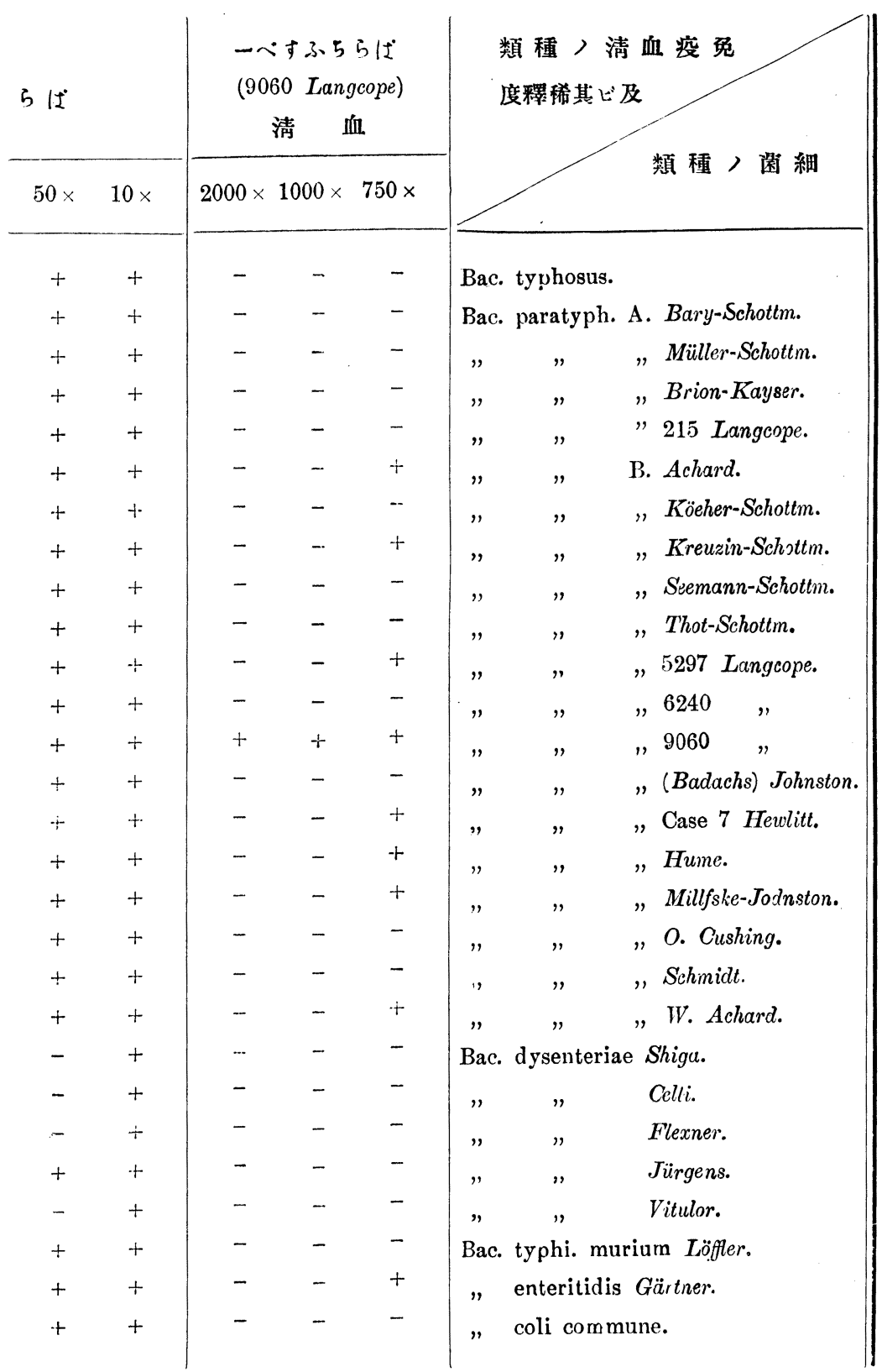




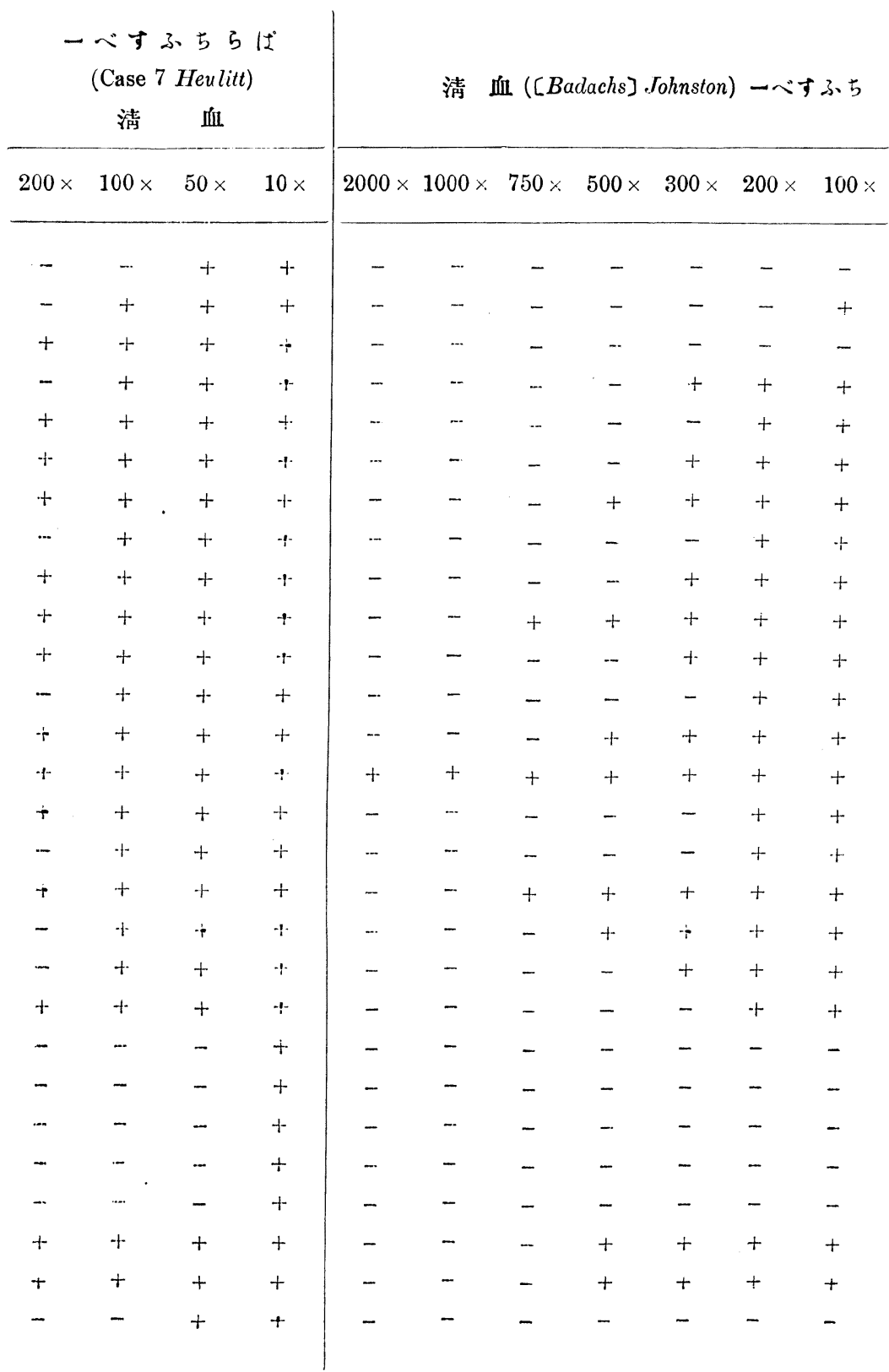


類種, 清血疫免

清血 (Case 7 Hewlitt)ーべすふららば
度釋稀其じ及
Bac. typhosus.

Bac. paratyph. A. Bary-Schottm.

$$
\text { , }
$$$$
\text { , Müller-Schottm. }
$$$$
\text { , , }
$$$$
\text { "Brion-Kays.r. }
$$$$
\text { , , }
$$$$
\text { „, } 215 \text { Langcope. }
$$

" $\quad$

B. Achard,

, "

„Koeher-Schottm.

, "

, Kreuzin-Schottm.

„Seemann-Schottm.

"Thot-Schottm.

, 5207 Langcope.

" $6210 \quad$ "

,9060 "

" (Badachs) Johnston.

, Case 7 Heulitt.

"Hume.

, Millske-Johnston.

, O. Cushing.

„Schmidt. ,W. Achard.

" "

Bac. dysenteriae Shiga.

$\begin{array}{lll}, & , & \text { Celli. } \\ , & , & \text { Iilexner. } \\ ", & , & \text { Jürgens. } \\ , & , & \text { Vitulor. }\end{array}$

Bac. typhi murium Löffler.

", enteritidis Gärtner.

" coli commune. 
（153）述郎四荠佳帖及郎太福永吉

清血 (Hume) 一へするすらな゙

\begin{tabular}{|c|c|c|c|c|c|c|c|c|c|}
\hline $10 x$ & $2000 \times$ & $1000 \times$ & $750 \times$ & $500 \times$ & $300 \times$ & $200 \times$ & $100 \times$ & $50 \times$ & $10 x$ \\
\hline+ & $\ldots$ & - & - & - & - & - & - & + & + \\
\hline+ & - & $\ldots$ & - & - & $\ldots$ & + & + & + & + \\
\hline+ & $\ldots$ & $\ldots$ & - & - & $\ldots$ & - & $t$ & + & + \\
\hline+ & $\cdots$ & - & - & $\because$ & + & + & + & + & + \\
\hline$f$ & - & - & - & - & - & + & + & + & + \\
\hline$t$ & - & - & $\ldots$ & + & + & + & + & + & + \\
\hline+ & - & $\sim$ & - & - & - & - & + & + & + \\
\hline+ & - & $\ldots$ & - & - & $\uparrow$ & + & + & + & + \\
\hline+ & -- & - & $\cdots$ & - & $=$ & + & + & + & + \\
\hline+ & - & - & - & - & - & - & + & + & + \\
\hline+ & - & - & $\cdots$ & - & - & - & + & + & + \\
\hline+ & $\cdots$ & - & - & + & + & + & + & + & + \\
\hline+ & - & - & $\ldots$ & - & - & - & $t$ & + & + \\
\hline+ & - & - & - & - & - & - & + & + & + \\
\hline+ & - & - & - & - & - & + & + & + & + \\
\hline+ & - & + & + & + & + & + & + & + & + \\
\hline+ & $\cdots$ & -. & - & - & + & + & + & + & + \\
\hline+ & $\ldots$ & $\cdots$ & $\ldots$ & + & + & + & + & + & + \\
\hline+ & $\cdots$ & $\ldots$ & - & - & - & + & + & + & + \\
\hline+ & $\cdots$ & $\cdots$ & - &.. & + & + & + & + & + \\
\hline+ & $\cdots$ & $\ldots$ & - & - & - & - & - & - & + \\
\hline+ & $\cdots$ & $\ldots$ & $\ldots$ & $\cdots$ & -- & - & $\ldots$ & - & + \\
\hline+ & $\ldots$ & $\ldots$ & - & - & - & - & - & - & + \\
\hline+ &.- & $\ldots$ & $\ldots$ & - & $\cdots$ & - & $\ldots$ & + & + \\
\hline 4 & - & $\ldots$ & $\ldots$ & $-\cdots$ & - & - & $\ldots$ & -. & + \\
\hline+ & $\ldots$ & $\ldots$ & $\ldots$ & + & + & + & 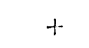 & + & + \\
\hline+ & $\ldots$ & $\cdots$ & - & - & + & + & + & + & + \\
\hline+ & $\ldots$ & -. & $\ldots$ & - & - & $\ldots$ & - & + & + \\
\hline
\end{tabular}




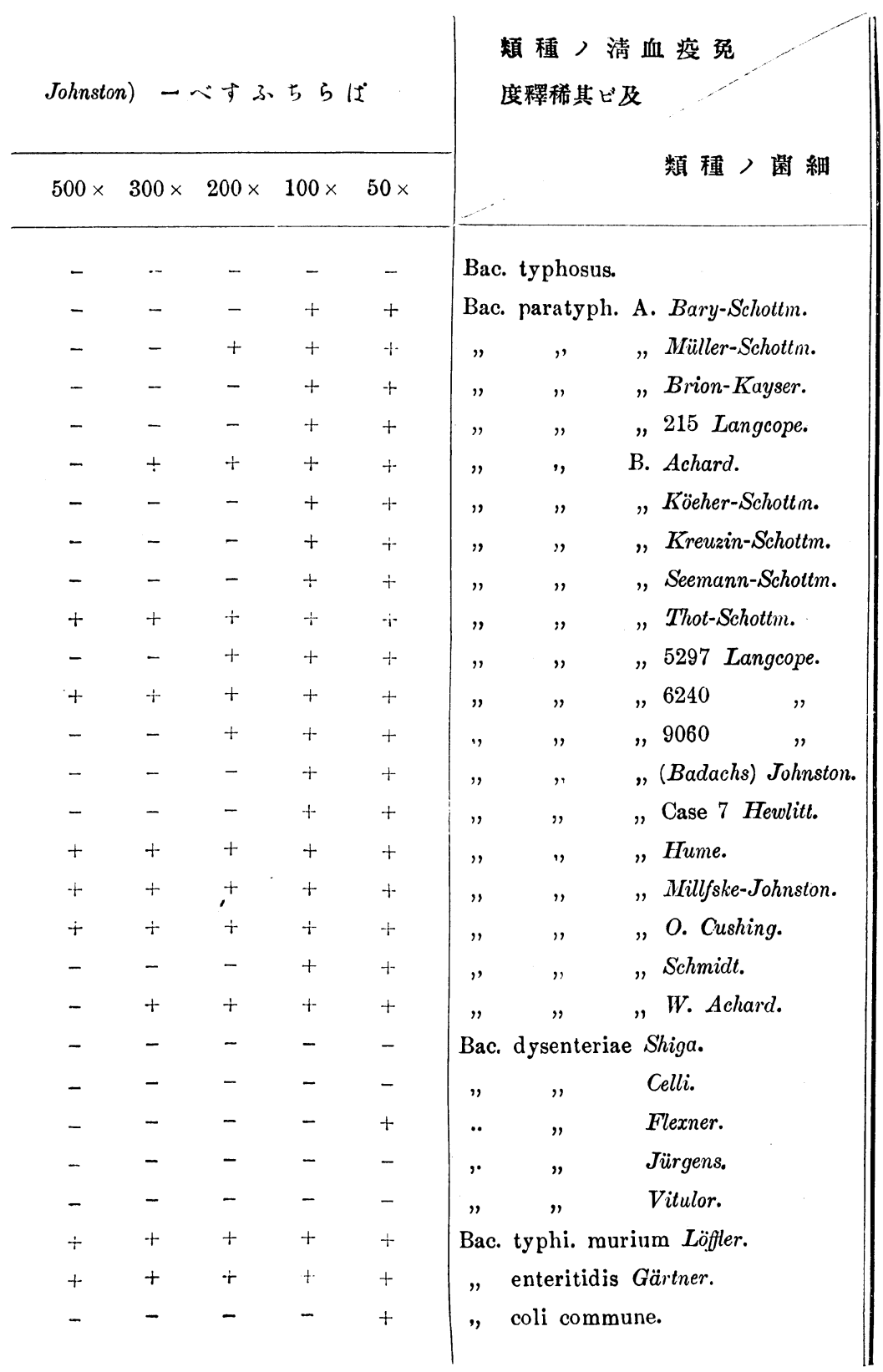


(155) 述郎四彥偖帖及郎太福永吉

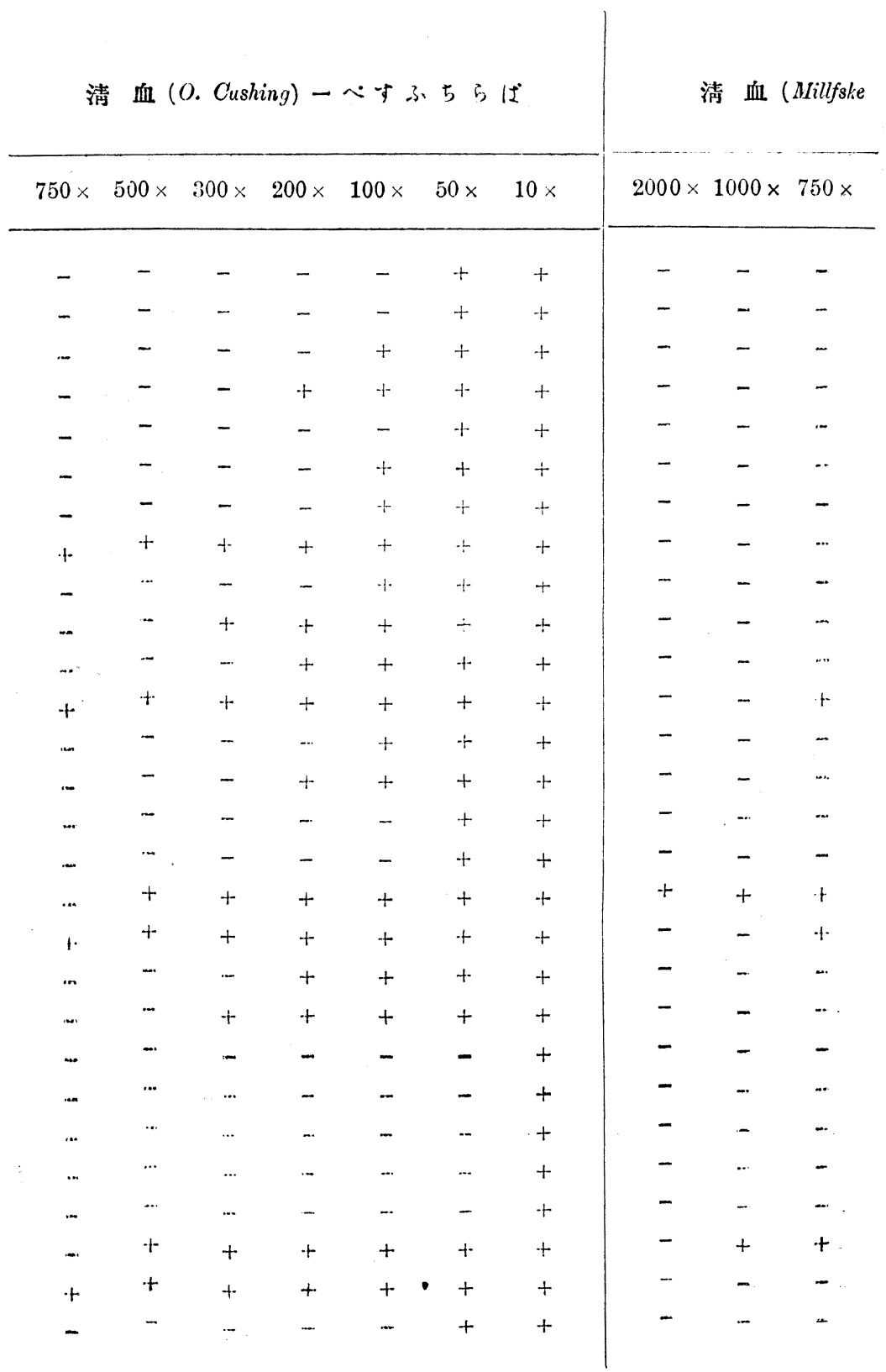




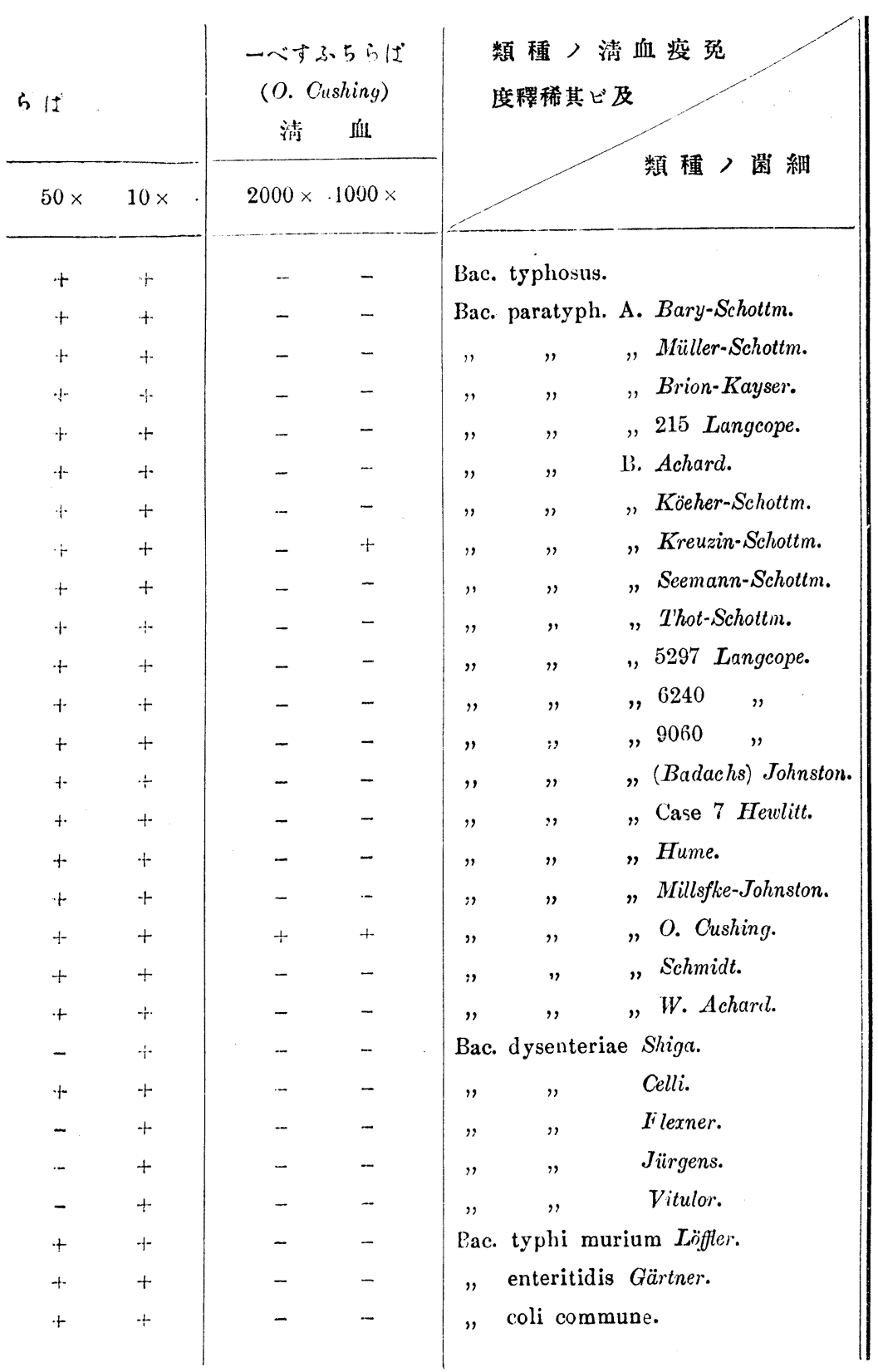


（157）迅㿟四坴佳帖及郎太福永吉

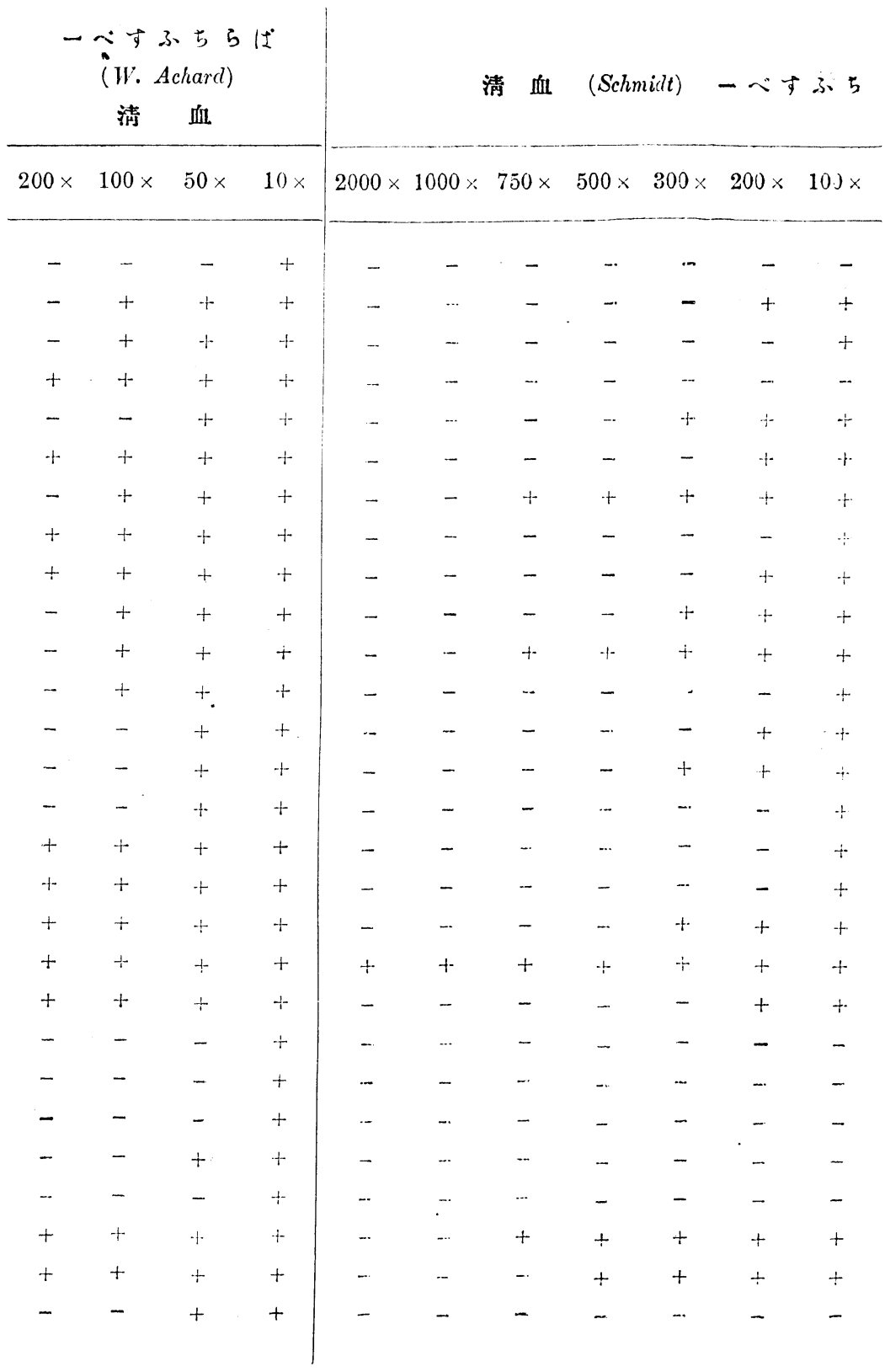




\begin{tabular}{|c|c|c|c|c|c|c|c|}
\hline \multicolumn{5}{|c|}{ 清血 (W. Achard) 一べすふららば } & \multirow{2}{*}{\multicolumn{3}{|c|}{ 類 種 ノ清血疫免 }} \\
\hline \multicolumn{5}{|c|}{$2000 \times 1000 \times 750 \times \quad 500 \times 300 \times$} & & & \\
\hline- & - & - & - & - & \multicolumn{3}{|c|}{ Bac. typhosus. } \\
\hline - & - & - & - & - & \multicolumn{3}{|c|}{ Bac. paratyph. $\Lambda$. Bary-Schottm. } \\
\hline- & - & - & - & - & \multicolumn{3}{|c|}{$" \quad \quad, \quad$ Müller-Schottm. } \\
\hline- & $\ldots$ & - & - & + & \multicolumn{3}{|c|}{$" \quad, \quad$, Brion-Kayser. } \\
\hline . & $\ldots$ & - & - & - & \multicolumn{3}{|c|}{$" \quad \quad \quad \quad 215$ Langcope. } \\
\hline- & - & - & - & + & \multicolumn{3}{|r|}{ B. Achard. } \\
\hline$\cdots$ & - & - & - & - & \multicolumn{3}{|r|}{ "Köeher-Schottm. } \\
\hline- & - & + & + & + & $"$ & $"$ & "Kreuzin-Schottm. \\
\hline- & - & - & - & + & \multicolumn{2}{|c|}{$" \quad " \quad$} & „Seemann-Schottm. \\
\hline- & - & - & - & - & \multicolumn{2}{|c|}{$" \quad . \quad}$, & "Thot-Schottm. \\
\hline$\cdots$ & - & - & - & - & \multicolumn{2}{|c|}{$" \quad \quad}$, & " 5207 Langcope. \\
\hline- & - & - & - & - & \multicolumn{2}{|c|}{$", \quad}$, & $" 6240 \quad "$ \\
\hline- & - & - & - & - & \multicolumn{2}{|c|}{$", \quad \quad}$, &, $9060 \quad$, \\
\hline- & - & - & - & - & \multicolumn{2}{|c|}{$" \quad \quad "$} & "(Barachs) Johnston. \\
\hline- & - & - & - & - & \multicolumn{2}{|c|}{$" \quad "$} & " Case 7 Hewlitt. \\
\hline- & - & + & + & + & \multicolumn{2}{|c|}{$" \quad \quad "$} & "Hume. \\
\hline- & - & - & - & + & \multicolumn{2}{|c|}{,$\quad \quad}$, & „Millfske-Johnston. \\
\hline$\cdots$ & - & - & - & - & \multicolumn{2}{|c|}{$" \quad}$, & "O. Cushing. \\
\hline- & - & - & + & + & \multicolumn{2}{|c|}{$" \quad \quad "$} & ,Schmidt. \\
\hline+ & + & + & + & + & $"$ & , & ,W. Achard. \\
\hline- & - & - & - & - & \multicolumn{3}{|c|}{ Bac. dysenteriae Shiga. } \\
\hline- & - & - & - & - & , & $"$ & Celli. \\
\hline- & - & - & - & - & & , $\quad$, & Flexner. \\
\hline- & - & - & - & - & $"$ & " & Jürgens. \\
\hline- & - & - & - & - & $"$ & ", & Vitulor. \\
\hline- & - & + & + & + & & typhi & rium Löfler. \\
\hline- & - & $\cdot-$ & - & + & ” & enterit & Gärtner. \\
\hline- & - & - & - & - & & coli co & une. \\
\hline
\end{tabular}


(159) 述郎四㐗佐帖及郎太福永吉

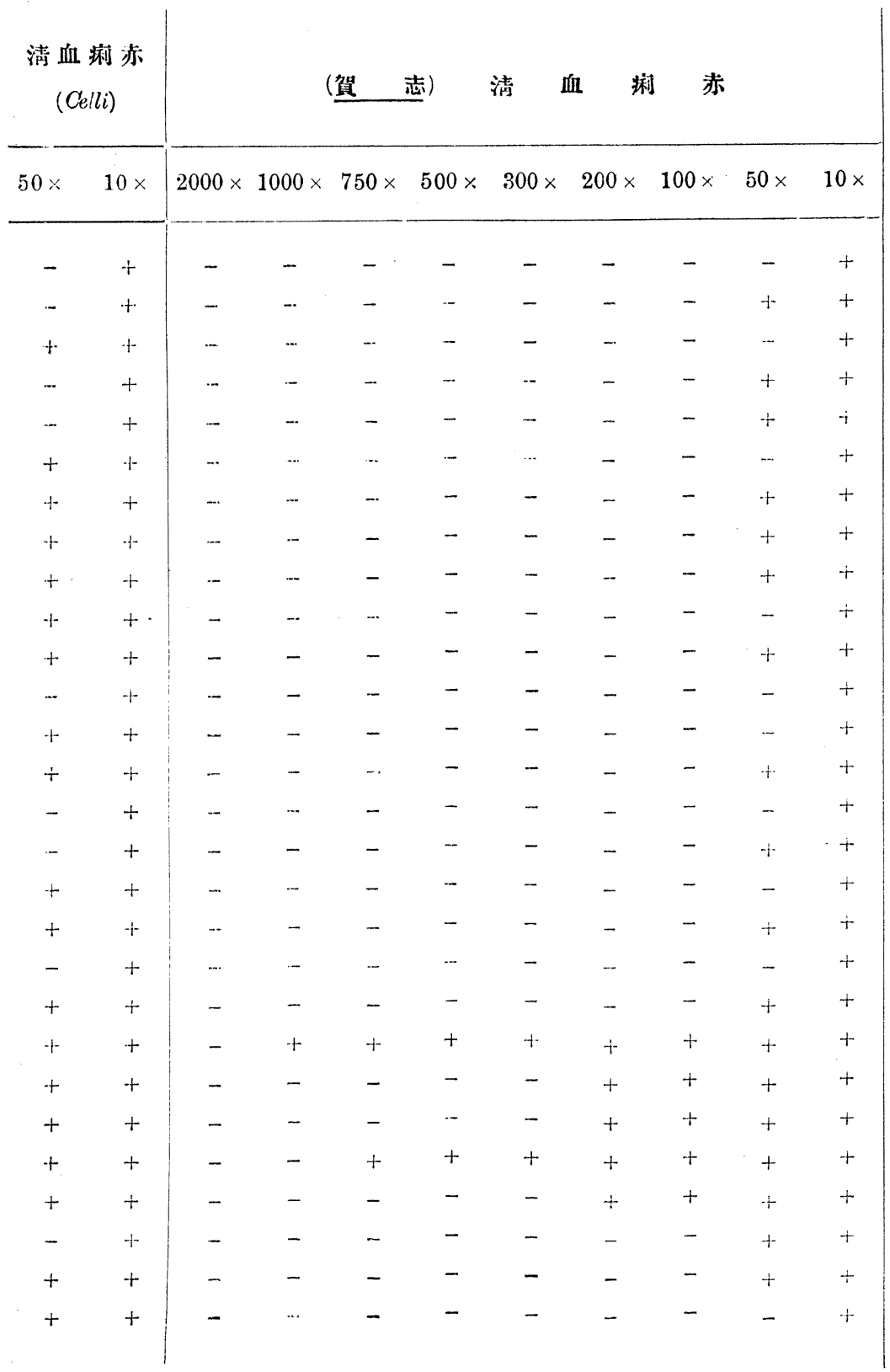




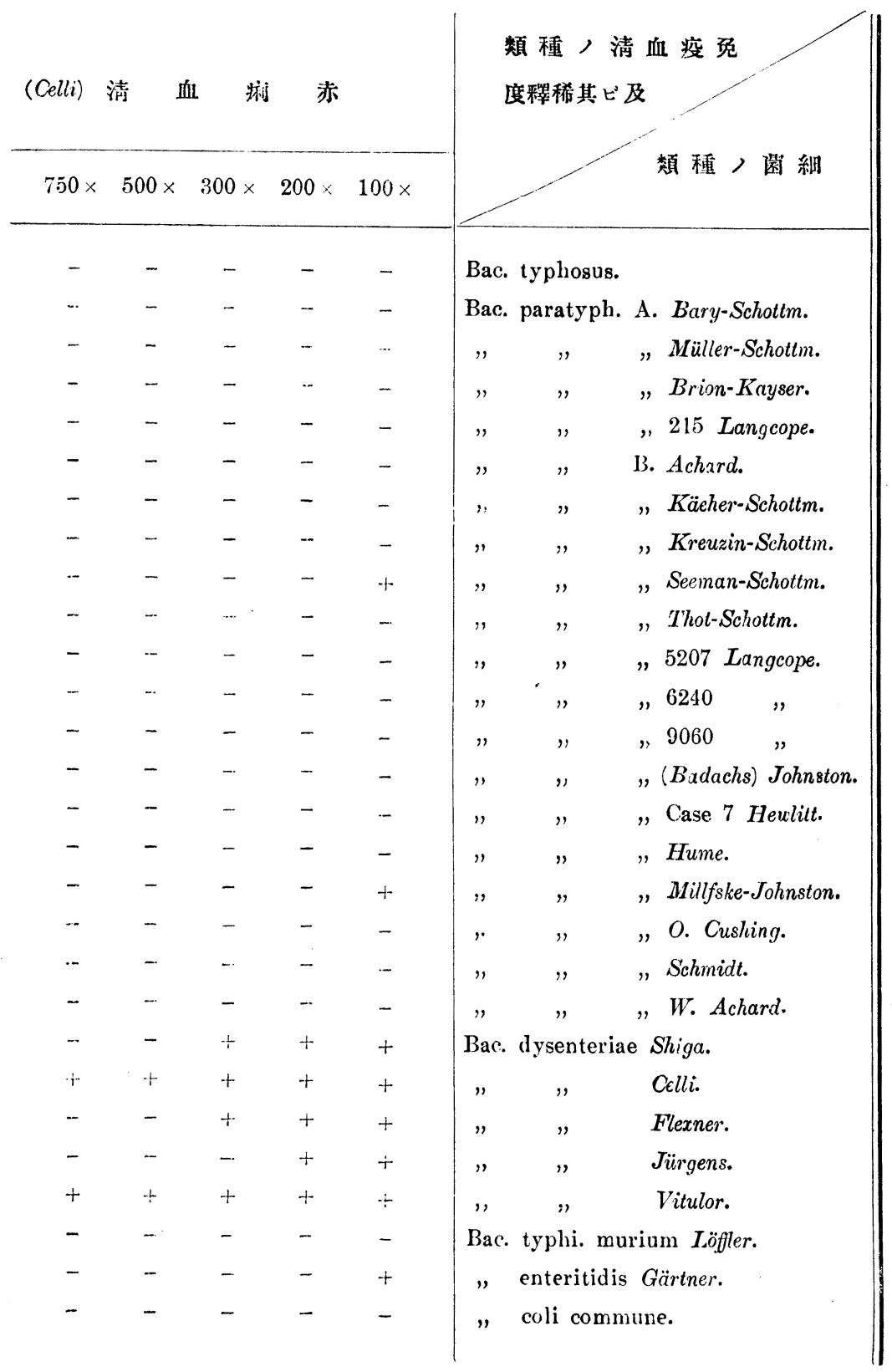




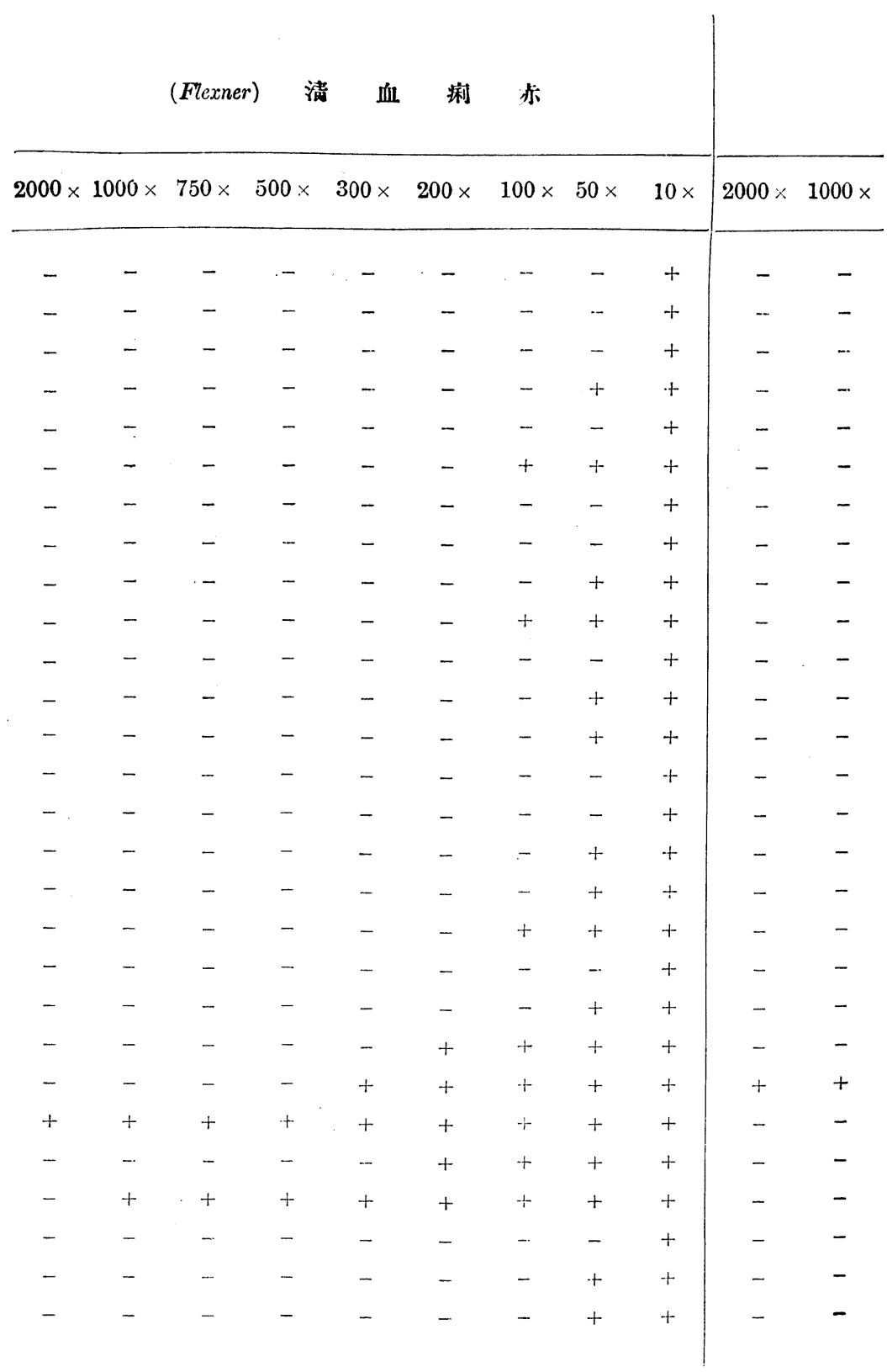


洋 血浰洂

類種 清血疫免

度䆁稀其ビ及

\section{類種 つ笑細}

Bac. typhosus.

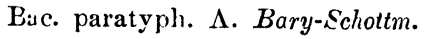

\begin{tabular}{|c|c|c|}
\hline$"$ & $"$ & „Müller-Schottm. \\
\hline ", & $"$ & "Brion-Kayser. \\
\hline " & $"$ & "215 Langcope. \\
\hline$"$ & $"$ & B. Achurd. \\
\hline$"$ & $"$ & "Köehtr-Schottm. \\
\hline " & $"$ & "Kreuzin-Schottm. \\
\hline$"$ & $"$ & "Seemann-Schottm. \\
\hline " & $"$ & , Thot-Schottm. \\
\hline$"$ & $"$ & " 5207 Langcope. \\
\hline$"$ & $\therefore$ &, $6240 \quad "$ \\
\hline " & $"$ &, $9060 \quad$, \\
\hline$"$ & $"$ & "(Barachs) Johnston. \\
\hline$"$ & $"$ & "Case 7 Hexlitt. \\
\hline$"$ & $"$ & "Hume. \\
\hline " & , & "Millfske-Johnston. \\
\hline$"$ & $"$ & "O. Cushing. \\
\hline$"$ & 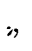 & , Schmidt. \\
\hline " & " & "W. Achard. \\
\hline
\end{tabular}

Bac. dysenteriae Shiga.

$$
\begin{array}{lll}
, & , & \text { Celli. } \\
, & , & \text { Flexner. } \\
, & , & \text { Jürgens. } \\
, & , & \text { Vilulor. }
\end{array}
$$

Bac. typhi murium Löfler.

" enteritidis Gärtner.

, coli communc. 
(163) 迅郎四裳佳帖及郎太福永吉

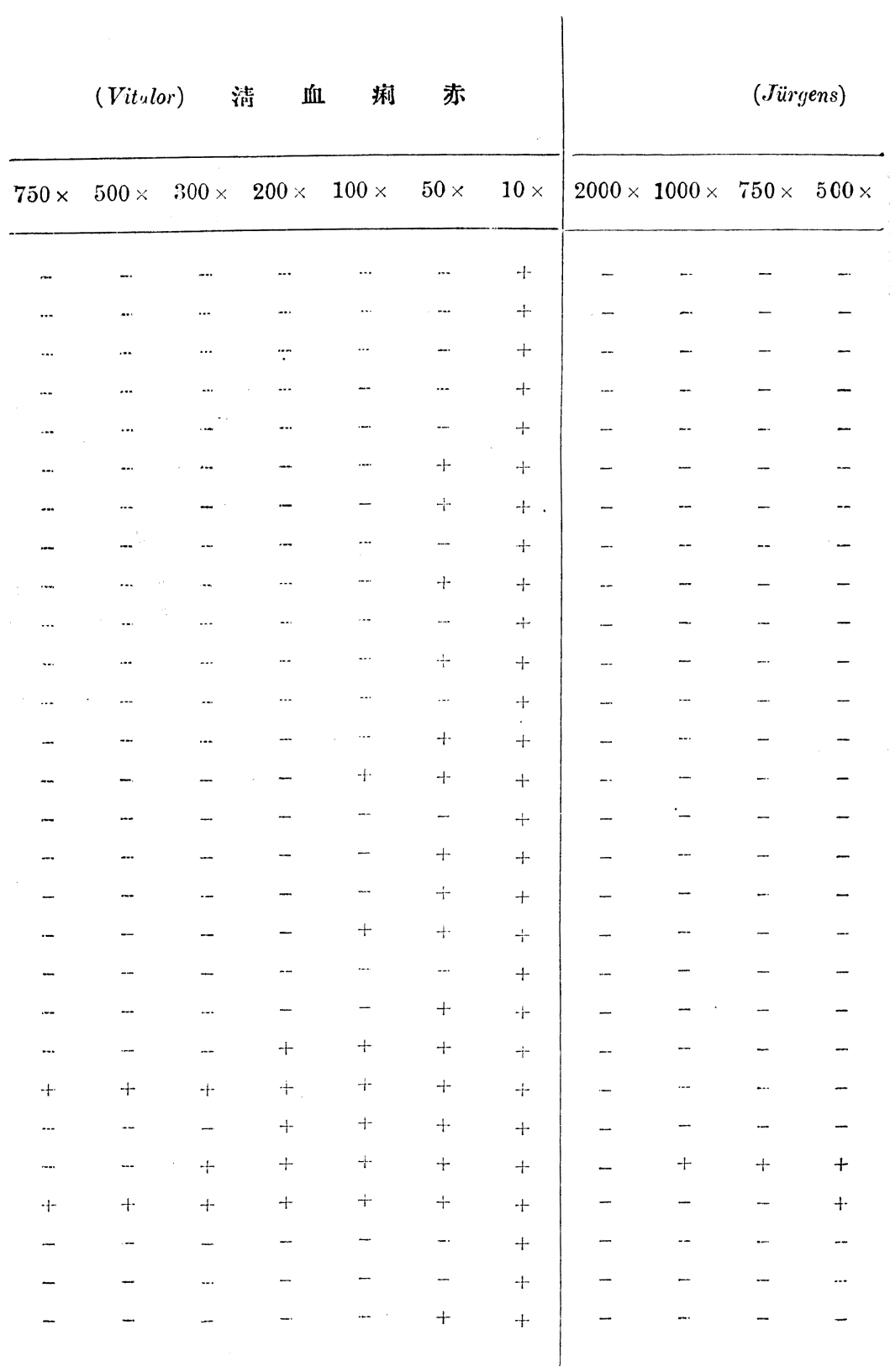




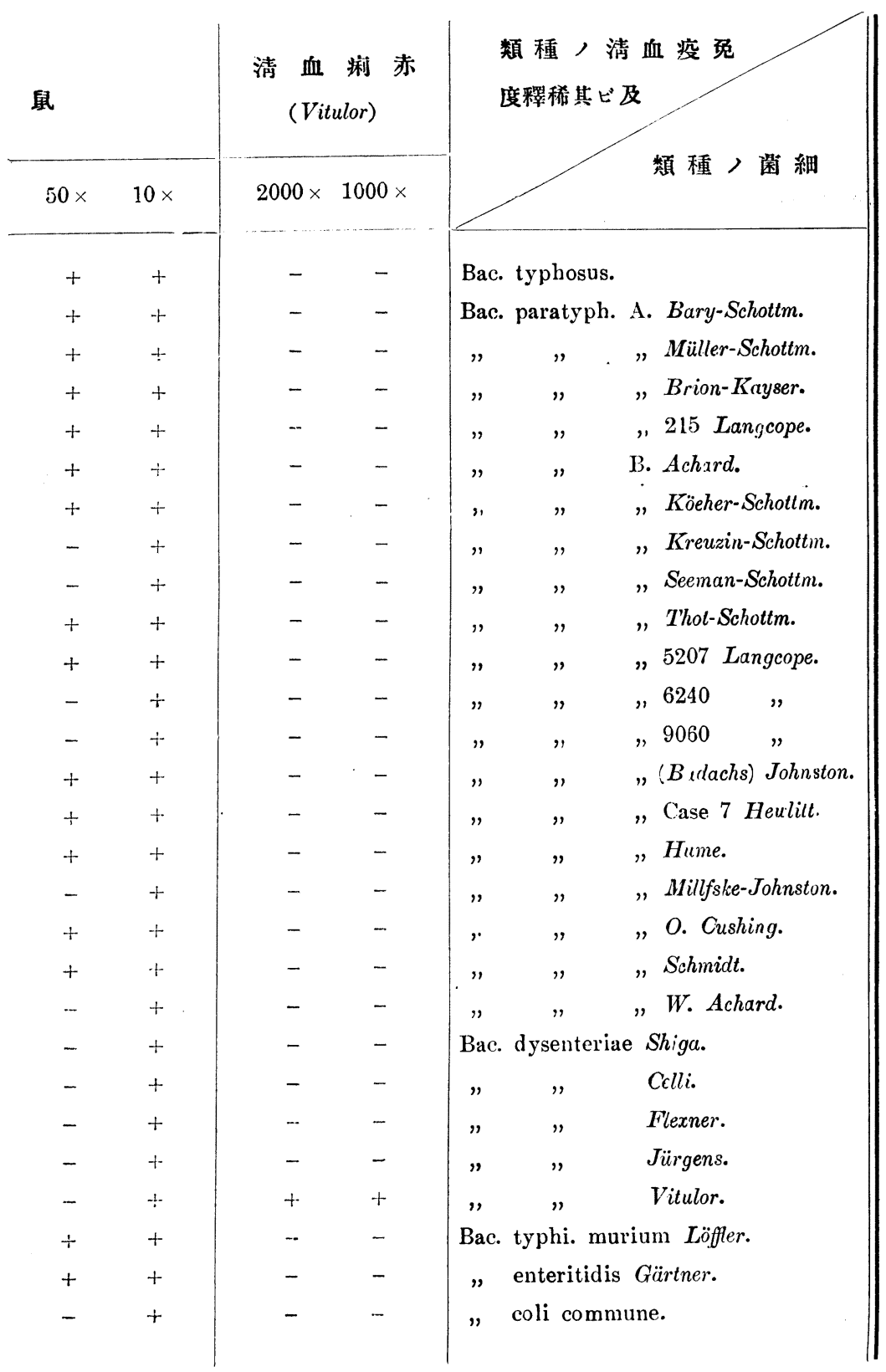


（165）述郎四茎佬帖及郎太福永吉

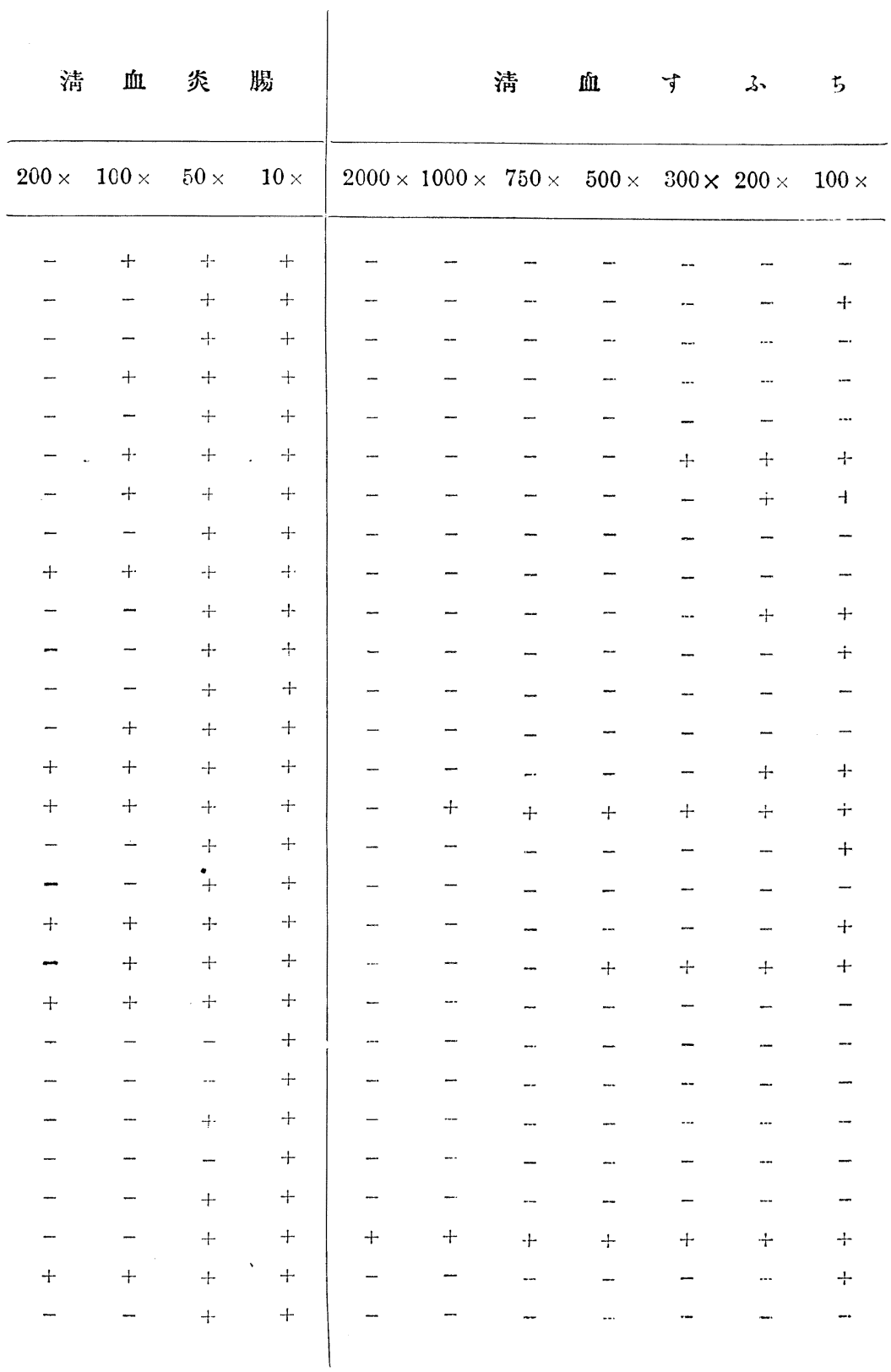




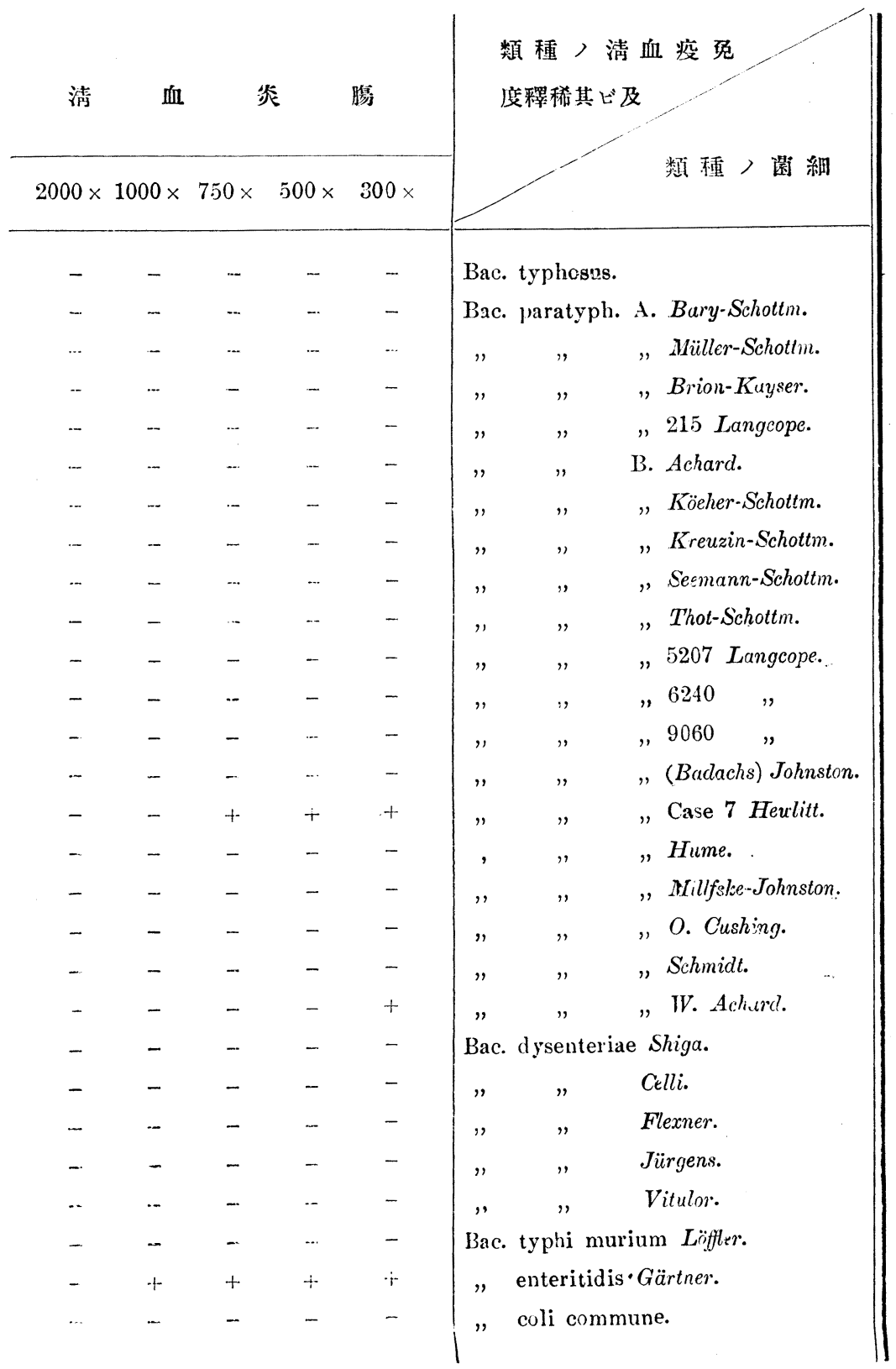


（167）还郎四觉佳帖及郎太福永吉

すり應

桿テ 学該 理 血家健

菌相呈成的 清蒐康

清血腸大通著

五. 績

如二ぱ 表 監

キ 反ら,

八應 ち 示

ぱ、キふス

ら現す處

ち 八桿 二

小七菌 $\exists$

すリ少 レ

血 加 ビ バ

清 乙 赤 腸

二却痐炎

對 テ 桿 桿

继 菌 菌

テ正 八 八

著凝此 ち

集等

寸反菌方

類 應 種 血

屬 ヨ 省

反 リ以 二

應優テ ヨ

チ儿得リ

有 モ夕テ

セノル强

リア据大

リ疫

又血 ル

鼠 清 類

ち 二屬

子 $\exists$ 反 
章テテン最或

二絡予要毛八

之三等 入 親

基共儿密

述自遂二于

的三凝儿勝㠰元

于各集關劣此

達菌原俰

三 應

初對三有

メ

テル リ

爷調李示

菌 理”確 如

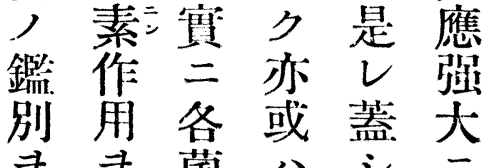

尹 7 菌八シ

明檢 $尹$ 共該

睹定鑑通菌テ

子七別 一種眞

ラリ入受分

シ然儿凝形凝

ムリコ素態集

儿而卜学㕅

コ シ 頗具及應

卜テ儿有培卜

于予困 入養著

得等難儿基 シ

夕八ナ二上キ

是 是 $\exists$ 等逕

依三是儿二庭

厂 $\exists$ 寻於

次少於亏示
カル桿二

尹 菌 䅾

實毛別二

驗 亦 ス し

セ哎ル

リ 5 ב

ᄂ 5

西系能 $\tau$ 能野京公了 八モ血ザ及 ザ亦清儿く リ) 該 $=$ । キ反對卜こ 應 シ 二㳊報 $\exists \quad ら \quad セ ゙ る$ リち 少 テ ‘赤 終すく痢 二桿口桿 鼠菌ち菌

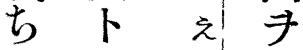
子同了凝 士 及集 及稀ま仅 ば釋い應 万度に皇 ち 70 皮 ふデけリ す 凝 八 桿集 鼠相 菌七ち互 チラふ完 明儿高全 
（169）述郎四彥传帖及郎太福永吉

調 者モ 即テみ引゙ 赤

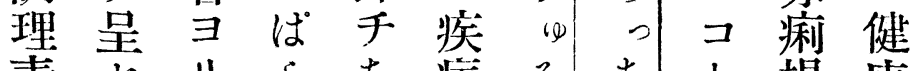

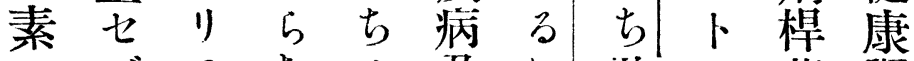

二ズモちふ及㣗文八菌調

寻是當子す病る! 方悓、理

リし該す患原及文之結素

テ盖菌桿者菌む京ば核公

畺シ二菌八ノつた 桿 特

正 調 對 二 健 診 ふ1 0 菌 罣

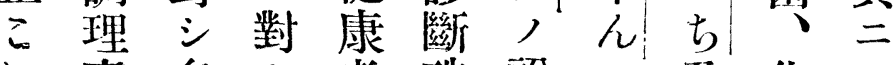

社素含者殊說少化

らノ量テ寻二二同方膿テ

弧特ノ八リ新 $\exists$ 時之性種

菌異調何モシ こ 三す蕾類素:

及性理等ちキバ急た萄—

其三素作少病免疫 | 桀与

類全 $\Rightarrow$ 用 原疫調ん球亏

似 有大桿菌調理亚菌

弧歸入ク菌人理素三等例

菌因儿之二認素, 帖三へ

並入モ三對識公特佐對 バ

二ルち反 $シ$ 方亦種, 入ち

其モふ シ テ確特ナ得ルふ

類ノすテ多賽種儿驗者す

似ナ桿ば量ナノコニト桿

弧り菌ら, ラモトヨ八菌

菌佾二ち調シノチ百二

各し對 ふ理

自嵒 シ 素得 シ 少明相入

手ち虫手儿テリカ異ル

互之毫者含:之しナ学調

二八モ公有云二よりル理

鑑否作健入八ヨ口又者素

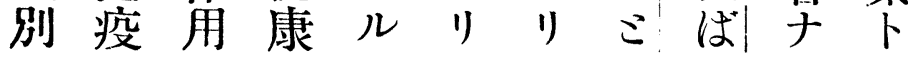




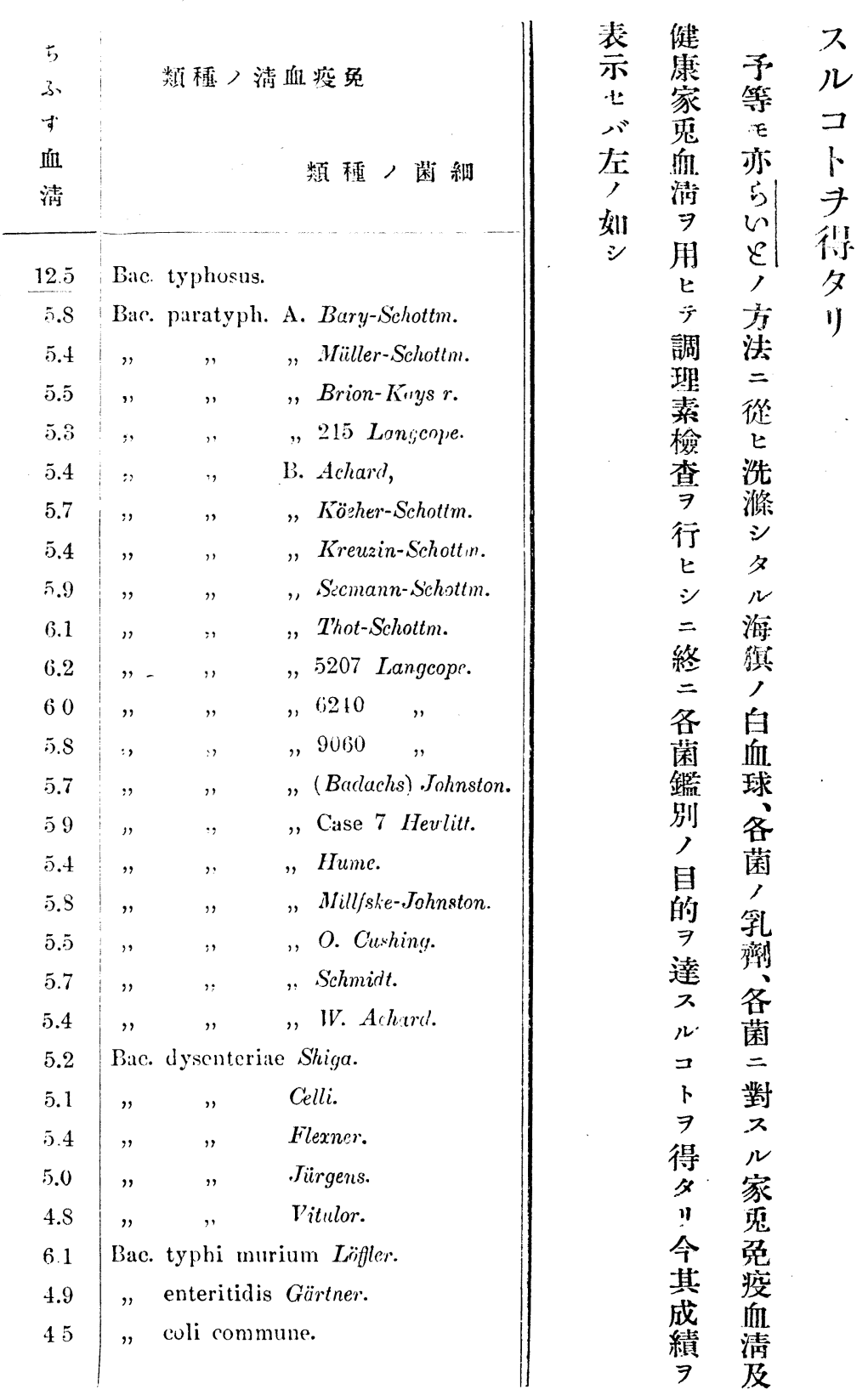


（171）述郎四䓞传帖及郎太福永吉

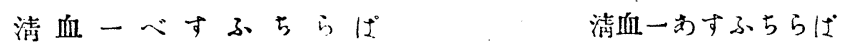

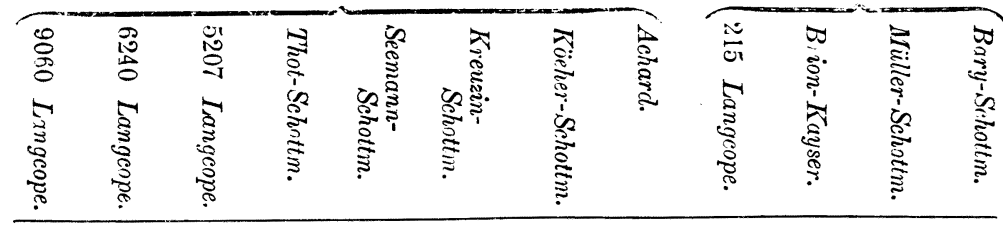

$\begin{array}{llllllllllll}4.2 & 4.3 & 4.5 & 4.1 & 4.4 & 4.3 & 4.3 & 4.1 & 4.2 & 4.3 & 4.5 & 4.2\end{array}$

$\begin{array}{llllllllllll}5.9 & 5.8 & 6.1 & 5.6 & 5.5 & 5.7 & 5.3 & 5.8 & 6.3 & 6.1 & 6.3 & 18.7\end{array}$

$\begin{array}{llllllllllll}5.8 & 6.1 & 5.8 & 5.7 & 5.6 & 5.8 & 5.9 & 5.7 & 6.1 & 6.3 & 19.2 & 6.2\end{array}$

$\begin{array}{llllllllllll}6.2 & 6.0 & 6.2 & 5.8 & 5.9 & 6.4 & 6.0 & 6.1 & 6.4 & 17.8 & 6.1 & 5.8\end{array}$

$\begin{array}{llllllllllll}6.1 & 5.9 & 6.2 & 5.9 & 6.3 & 6.2 & 6.1 & 6.2 & 18.2 & 6.0 & 6.2 & 6.1\end{array}$

$\begin{array}{llllllllllll}6.5 & 6.4 & 6.3 & 6.2 & 6.4 & 6.1 & 6.2 & 17.5 & 5.9 & 5.7 & 5.5 & 5.8\end{array}$

$\begin{array}{llllllllllll}6.2 & 6.3 & 6.4 & 6.3 & 6.1 & 6.3 & 19.3 & 5.8 & 5.6 & 5.5 & 5.7 & 5.6\end{array}$

$\begin{array}{llllllllllll}5.9 & 5.8 & 6.1 & 5.9 & 6.3 & 20.4 & 6.2 & 6.2 & 6.1 & 5.8 & 5.5 & 5.7\end{array}$

$\begin{array}{llllllllllll}5.8 & 6.3 & 6.0 & 6.0 & \underline{18.5} & 6.2 & 5.8 & 6.1 & 5.7 & -5.8 & 9.1 & 6.2\end{array}$

$\begin{array}{llllllllllll}6.3 & 6.2 & 6.5 & 17.8 & 6.2 & 6.1 & 6.3 & 6.5 & 6.9 & 5.9 & 6.5 & 7.1\end{array}$

$\begin{array}{llllllllllll}62 & 6.4 & 20.2 & 6.1 & 5.8 & 6.1 & 6.2 & 5.8 & 6.2 & 6.1 & 6.2 & 6.3\end{array}$

$\begin{array}{llllllllllll}6.5 & 19.6 & 63 & 5.7 & 6.2 & 5.9 & 5.6 & 5.8 & 5.7 & 5.8 & 6.1 & 6.2\end{array}$

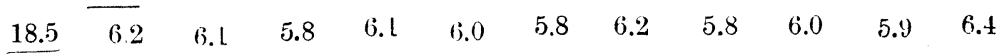

$\begin{array}{llllllllllll}9.2 & 6.4 & 6.5 & 5.9 & 6.2 & 6.3 & 62 & 6.3 & 5.9 & 5.7 & 5.8 & 6.2\end{array}$

$\begin{array}{llllllllllll}6.1 & 6.1 & 5.9 & 5.7 & 5.8 & 5.9 & 5.7 & 5.8 & 6.1 & 5.9 & 5.7 & 6.0\end{array}$

$\begin{array}{llllllllllll}6.2 & 6.2 & 5.8 & 5.5 & 6.1 & 5.8 & 5.9 & 5.8 & 5.8 & 6.1 & 5.6 & 5.5\end{array}$

$\begin{array}{llllllllllll}6.2 & 6.3 & 6.5 & 6.3 & 6.2 & 6.0 & 6.1 & 6.1 & 5.6 & 5.5 & 5.9 & 5.8\end{array}$

$\begin{array}{llllllllllll}6.1 & 6.4 & 6.3 & 6.2 & 5.9 & 6.1 & 5.8 & 5.8 & 5.8 & 5.7 & 5.7 & 5.7\end{array}$

$\begin{array}{llllllllllll}6.2 & 6.1 & 5.8 & 5.8 & 6.1 & 5.8 & 5.9 & 5.7 & 5 \cdot 5 & 5.7 & 5.8 & 6.3\end{array}$

$\begin{array}{llllllllllll}6.0 & 6.2 & 6.4 & 5.5 & 6.2 & 6.4 & 15.1 & 6.3 & 5.6 & 5.8 & 5.5 & 5.2\end{array}$

$\begin{array}{llllllllllll}5.0 & 4.9 & 4.7 & 4.8 & 4.7 & 4.8 & 4.9 & 4.8 & 5.1 & 4.8 & 5.3 & 5.0\end{array}$

$\begin{array}{llllllllllll}5 \cdot 1 & 5.2 & 4.8 & 5.1 & 4.8 & 5.2 & 5.0 & 5.1 & 4.9 & 5.1 & 5.2 & 4.8\end{array}$

$\begin{array}{llllllllllll}5.3 & 4.8 & 5.1 & 4.9 & 5.0 & 5.3 & 5.4 & 5.5 & 4.8 & 5.0 & 5.1 & 5.3\end{array}$

$\begin{array}{llllllllllll}4.9 & 5.3 & 5.0 & 5.4 & 5.2 & 5.4 & 4.8 & 4.9 & 5.1 & 4.8 & 4.9 & 5.1\end{array}$

$\begin{array}{llllllllllll}4.8 & 5.1 & 4.8 & 4.7 & 4.8 & 5.3 & 5.1 & 5.2 & 5.7 & 5.2 & 48 & 4.7\end{array}$

$\begin{array}{llllllllllll}5.9 & 6.0 & \text { h.4 } & 6.5 & 6.1 & 6.4 & 6.3 & 6.2 & 58 & 6.0 & 5.9 & 5.8\end{array}$

$\begin{array}{llllllllllll}4.5 & 4.7 & 4.9 & 4.6 & 4.8 & 4.5 & 4.9 & 5.1 & 5.2 & 5.1 & 4.8 & 4.8\end{array}$

$\begin{array}{llllllllllll}4.7 & 4.5 & 5.0 & 4.4 & 4.7 & 46 & 4.7 & 4.6 & 4.7 & 4.8 & 4.4 & 4.6\end{array}$ 


\begin{tabular}{|c|c|c|c|c|c|c|}
\hline & 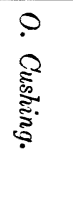 & 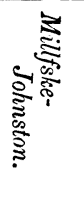 & 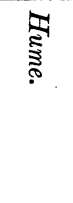 & 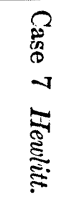 & 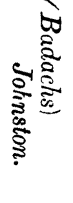 & 類種 つ清血疫宏 \\
\hline 4.5 & 4.6 & 4.4 & 4.5 & 4.3 & 4.4 & Bac. typhosus. \\
\hline 5.7 & 5.9 & 6.2 & 6.1 & 6.0 & 6.1 & Bac. paratyph. A. Bury-Schottm. \\
\hline 5.9 & 5.8 & 6.3 & 5.8 & 6.3 & 5.9 & $" \quad, \quad$, Müller-Schottm. \\
\hline 5.8 & 6.1 & 5.9 & 5.7 & 6.2 & 5.8 & "Brion-Kayser. \\
\hline 5.7 & 6.0 & 5.8 & 6.0 & 6.3 & 6.2 & "215 Langcope. \\
\hline 6.1 & 6.3 & 6.2 & 6.4 & 2.5 & 6.4 & I. Achard. \\
\hline 6.4 & 6.5 & 6.3 & 6.2 & 6.0 & 6.3 & „Kö̈her-Schottm. \\
\hline 6.2 & 6.2 & 6.0 & 6.5 & 6.6 & 6.5 & , Kreuzin-Schottm. \\
\hline 6.5 & 6.1 & 6.5 & 6.3 & 6.2 & 5.7 & "Seemann-Schotlm. \\
\hline 6.3 & 6.5 & 6.2 & 6.1 & 6.4 & 6.0 & "Thot-Schottm. \\
\hline 6.2 & 6.0 & 6.3 & 6.2 & 6.7 & 6.5 & „ 5297 Langcope. \\
\hline 6.5 & 6.4 & 6.6 & 6.8 & 6.1 & 6.2 & $" 6240 \quad$, \\
\hline 6.4 & 6.6 & 6.5 & 6.1 & 6.2 & 6.6 &, $9060 \quad "$ \\
\hline 6.3 & 6.3 & 6.2 & 6.3 & 6.3 & $\underline{19.7}$ & "(Badachs) Johnston. \\
\hline 6.2 & 6.3 & 6.1 & 6.4 & $\underline{20.5}$ & 6.2 & " Case 7 Hewlitt. \\
\hline 6.1 & 6.0 & 6.4 & 20.8 & 6.7 & 6.4 & "Hume. \\
\hline 6.6 & 6.5 & $\underline{\Sigma 0.1}$ & 6.4 & 6.5 & 6.7 & „Millssle-Johnston. \\
\hline 6.5 & 198 & 6.4 & 6.5 & 6.3 & 6.0 & " O. Cushing. \\
\hline 20.7 & 6.3 & 6.5 & 6.3 & 6.1 & 6.3 & , schmidt. \\
\hline 6.6 & 6.0 & 6.2 & 6.1 & 6.2 & 5.9 & $" \quad, \quad, W \cdot$ Achard. \\
\hline 5.1 & 5.2 & 5.1 & 4.8 & 5.1 & 4.8 & Bac. dysenteriae Shiga. \\
\hline 5.2 & 5.1 & 4.9 & 5.1 & 4.8 & 5.0 & Celli. \\
\hline 5.3 & 4.9 & 4.8 & 4.9 & 5.2 & 4.9 & Flexner. \\
\hline 4.8 & 5.0 & 4.9 & 5.2 & 5.0 & 4.7 & Jürgens. \\
\hline 4.9 & 5.2 & 4.9 & 5.1 & 50 & 4.8 & $" \quad$ Vitulor. \\
\hline 6.4 & 6.3 & 5.9 & 6.2 & 6.3 & 6.1 & Bac. typhi. murium Löffer. \\
\hline 4.7 & 5.0 & 1.7 & 4.9 & 5.1 & 4.7 & $" \quad$ enteritidis Gärtner. \\
\hline 4.8 & 4.9 & 4.6 & 4.8 & 4.8 & 4.5 & " coli commune. \\
\hline
\end{tabular}


（173）䢑郎四吝传帖及郎太踾永吉

諸

菌如

多疫

少 血

類 清

屬 八

反當

應 該

于 菌

물

對

ル シ

モ テ

ノ著

ア 基

ル

モ强

該 夺

應 ル

調

真 理

正 素

調 作

理 用

素

作 現

用

二 他

比,

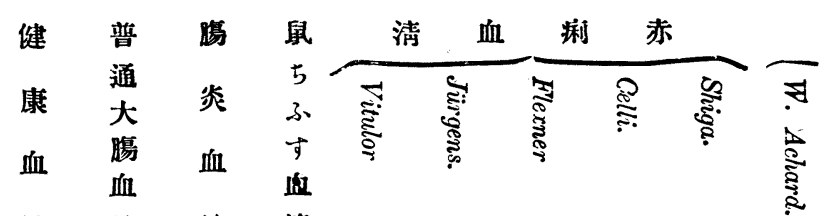

清 清 清 清

$\begin{array}{lllllllllll}4.3 & 4.3 & 4.9 & 4.3 & 4.2 & 4.4 & 4.3 & 4.5 & 4.4 & 4.5\end{array}$

$\begin{array}{llllllllll}5.7 & 5.8 & 5.9 & 5.8 & 5.9 & 5.8 & 5.7 & 5.8 & 5.7 & 5.8\end{array}$

$\begin{array}{llllllllll}5.7 & 5.7 & 6.1 & 5.9 & 5.7 & 5.9 & 5.8 & 5.9 & 5.8 & 5.9\end{array}$

$\begin{array}{llllllllll}5.6 & 5.6 & 5.8 & 6.1 & 5.5 & 5.7 & 5.8 & 5.7 & 5.6 & 5.7\end{array}$

$\begin{array}{llllllllll}5.7 & 5.9 & 5.7 & 5.9 & 5.6 & 5.6 & 5.5 & 5.6 & 5.7 & 5.9\end{array}$

$\begin{array}{llllllllll}5.8 & 5.8 & 5.9 & 6.2 & 5.7 & 5.8 & 5.9 & 6.1 & 6.0 & 5.8\end{array}$

$\begin{array}{llllllllll}5.8 & 5.9 & 6.2 & 6.3 & 5.3 & 5.5 & 5.5 & 5.9 & 5.8 & 6.3\end{array}$

$\begin{array}{llllllllll}5.9 & 6.1 & 6.5 & 6.4 & 5.7 & 5.9 & 5.7 & 6.0 & 5.8 & 5.9\end{array}$

$\begin{array}{llllllllll}5.8 & 6.2 & 6.3 & 6.5 & 5.6 & 6.2 & 6.1 & 5.9 & 6.1 & 6.2\end{array}$

$\begin{array}{llllllllll}5.7 & 6.0 & 6.1 & 6.1 & 5.6 & 6.6 & 5.9 & 5.8 & 5.7 & 6.4\end{array}$

$\begin{array}{llllllllll}5.5 & 5.9 & 6.3 & 6.2 & 5.7 & 5.8 & 6.0 & 5.9 & 5.7 & 6.0\end{array}$

$\begin{array}{llllllllll}5.6 & 6.5 & 6.4 & 6.5 & 6.0 & 5.9 & 5.9 & 5.7 & 5.6 & 6.3\end{array}$

$\begin{array}{llllllllll}5.4 & 6.2 & 6.1 & 6.4 & 5.4 & 5.7 & 5.7 & 5.8 & 5.8 & 6.5\end{array}$

$\begin{array}{llllllllll}5.7 & 6.0 & 6.2 & 6.3 & 5.9 & 5.6 & 5.5 & 5.4 & 5.9 & 6.2\end{array}$

$\begin{array}{llllllllll}5.6 & 6.2 & 6.4 & 6.6 & 5.7 & 5.8 & 5.9 & 5.7 & 5.6 & 64\end{array}$

$\begin{array}{llllllllll}.5 & 5.9 & 6.3 & 6.2 & 5.8 & 5.7 & 5.7 & 5.8 & 5.8 & 6.1\end{array}$

$\begin{array}{llllllllll}5.4 & 5.8 & 6.2 & 6.4 & 5.7 & 5.9 & 5.8 & 5.6 & 6.1 & 6.5\end{array}$

$\begin{array}{llllllllll}5.7 & 6.0 & 6.0 & 6.1 & 5.6 & 5.7 & 5.7 & 5.8 & 6.2 & 6.6\end{array}$

$\begin{array}{llllllllll}5.5 & 5.9 & 6.1 & 5.8 & 5.7 & 5.9 & 5.9 & 5.9 & 5.7 & 6.4\end{array}$

$\begin{array}{llllllllll}5.6 & 5.8 & 6.0 & 5.9 & 5.9 & 5.7 & 5.8 & 5.8 & 5.5 & 19.8\end{array}$

$\begin{array}{llllllllll}4.7 & 4.9 & 4.8 & 4.8 & 5.5 & 5.5 & 5.8 & 5.7 & 16.4 & 5.2\end{array}$

$\begin{array}{llllllllll}4.8 & 5.9 & 5.0 & 4.9 & 5.7 & 5.8 & 5.9 & 15.8 & 5.8 & 48\end{array}$

$\begin{array}{llllllllll}4.7 & 5.1 & 4.9 & 5.1 & 5.8 & 5.7 & \underline{162} & 5.9 & 5.6 & 4.8\end{array}$

$\begin{array}{llllllllll}4.8 & 5.0 & 4.9 & 4.8 & 5.9 & 15.6 & 5.8 & 5.6 & 5.5 & 5.1\end{array}$

$\begin{array}{llllllllll}4.8 & 4.8 & 4.7 & 4.9 & 16.1 & 5.8 & 5.7 & 5.8 & 5.8 & 5.2\end{array}$

$\begin{array}{llllllllll}4.5 & 5.6 & 5.7 & 16.9 & 5.4 & 5.6 & 5.5 & 5.5 & 5.8 & 6.3\end{array}$

$\begin{array}{llllllllll}4.7 & 5.1 & 17.2 & 5.1 & 5.0 & 5.1 & 4.8 & 4.9 & 5.0 & 4.8\end{array}$

$\begin{array}{llllllllll}4.6 & 16.8 & 4.7 & 4.8 & 5.2 & 5.3 & 5.1 & 5.0 & 4.7 & 4.8\end{array}$ 
ヨ 赤普 ス

リ痢通二ルー以

テ菌大、コ、上

他類腸 前卜形 實

菌 八楿記能態驗

卜活菌諸八學 セ

ノ潑八菌ズ上ル

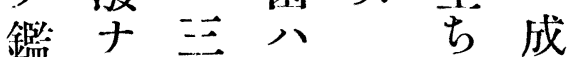

别儿留各交䋨

于分至必

容子八十

易運條方

十動ノ至

ラ 鞭十

有毛分

么 ス 焂

儿有ノ

モ シ 鞭

固 連 毛

有 動 于

運

動 前

于記 活

ク諸潑

且菌 ナ

ツ, ル

鞭 如連

毛 動

于 活 $尹$

備 潑 營

八于 $九$

ズラ =

是 ズ成

三 义 s

$す$ テ

總

は括

丂

七 其

要

变

、摘

鼠七

† バ

子 即

方

及左

膓,

炎 邚

, i

病

原

菌

于

相

Ti.

$=$

區

別
二 素

對 檢 極

シ 查

最法テ

E 八 微

有 万弱

力

市

シ テ

テは健

且 5 康

○血 括最公清

乇

完、ソ

全鼠

于 万卜

儿小砝

鑑守等

別、ド

法 膓 巡

夕炎庭

儿十

コ普 シ

卜通是

于大

認膓由

么及 少

赤 テ

㾥 予

, 等

病

原調

菌 理 
（175）述郎四裳佳蛅及郎太福永吉

一種 シ 現. 其き乳普

大分永六芯五他! 手四通三

少作儿、他少及凝、大、

用, 赤菌赤培遠固然腸培

$\exists i$ 痢卜 痢養藤卞し及養

有大槛 鑑 枮 基 培赤

シ 菌別菌上養痢 モ 痢上

七 ズ類 シ 類三基及培菌殊

及少得及於二者養類二

す該含儿普テ於通基

、菌水气通他テ大上相荣

ぱ族炭枀大菌装腸三互培

5 相素 $\mathrm{G}$ 腸二荠桿 $\exists$ 二養

ち 五二目桿此赤藏少區二

心二對二菌 シ 變人テ别

方分 八基

別儿各一發は斯別儿テ

鼠入醱菌日䘚ら晋

七儿酵悉乃旺ち發得卜ふ

ふ于作方至盛子生儿能す

す得用赤至子古渚八、

及ル三戀百ル心゙义公ズぱ

腹ナヨ天。等 | 普只ら

炎りリ几內三及通普 ち

菌 普 常

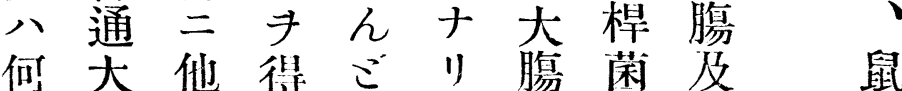

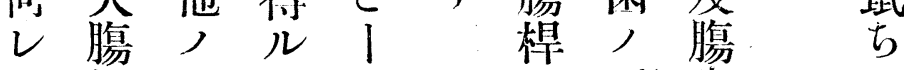

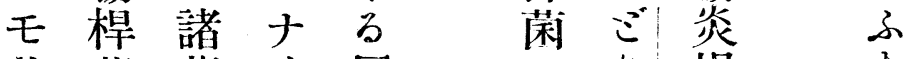

其菌菌り反 反 り 桿市

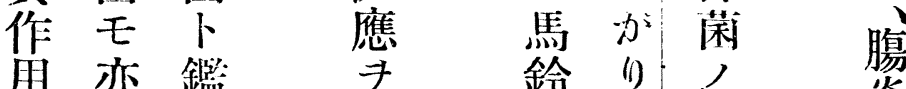

间特别發薯市牛炎 


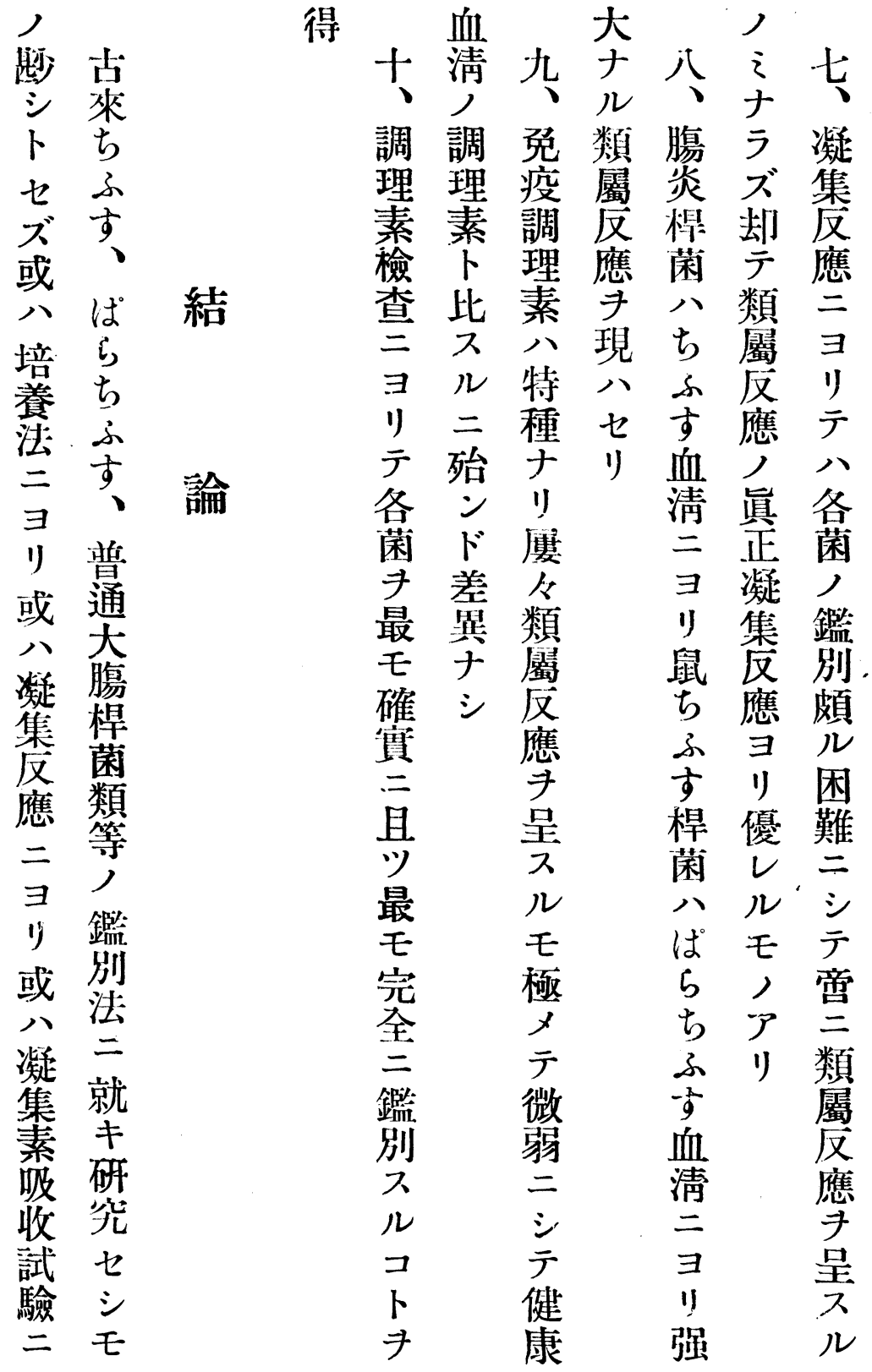


（177）述郎四意佐帖及郎太福永吉

ஸ

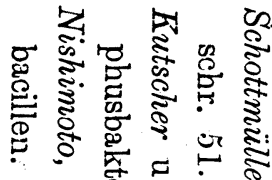

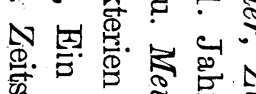

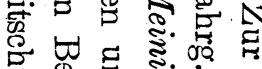

窟 范

$\rightarrow$ 造

년 둥

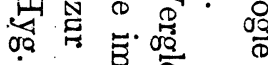

๒

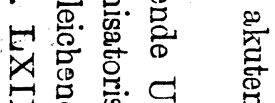

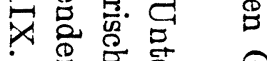

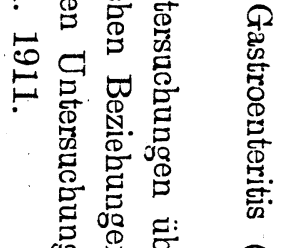

品

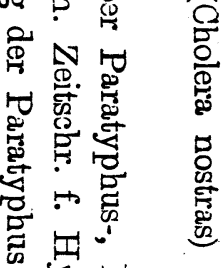

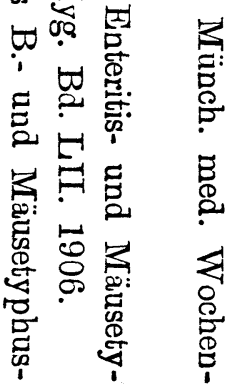

ツテリすキアヨ

最明故、二リリ

七 力三鼠ア然或

完ナ予ちラリ兵

全儿等ふ ズ卜 溶

ナガ八す然踓菌

參儿如ら、儿作

方准二モ角

考法全气炎予是二

書儿特調前八未生

コ種理通ら名將

目卜ノ素大的完多

于 性 八腸 心全又

茲于 昨及, 主補

二有二赤調 ル 體

嗞 諸 痢 理方轉

言 細 學 桿 素 法 向

入 菌者菌 檢二試

ノ族查ア驗

鑑 䂰 鑑 三 ラ

別究別 ヨ ズヨ

法三子 リ シ リ

卜

シリ的終種 レ

テ文キ二々ガ

最予達ちノ鑑

モ 等 2 子方 別

確ノルす酶

實實コ、ヨコ

二驗トばリセ

シ $=$ ら . 論

テ徵 得ち難 モ

且シ夕ふナ, 


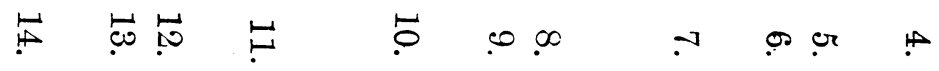

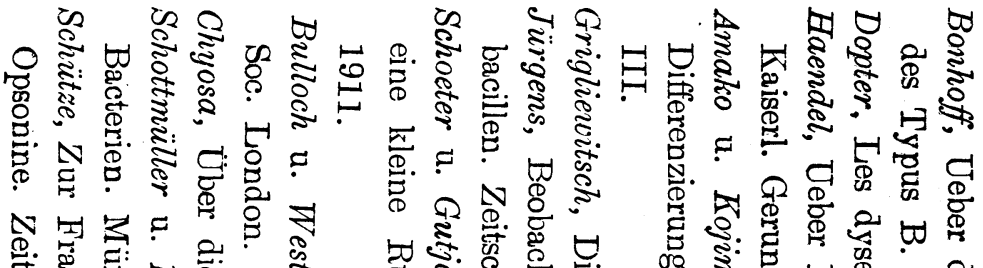

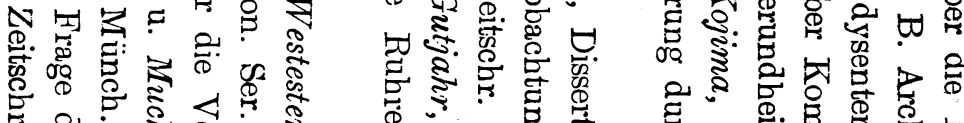

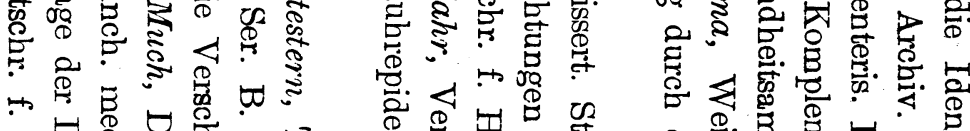

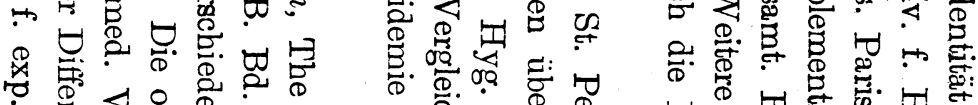

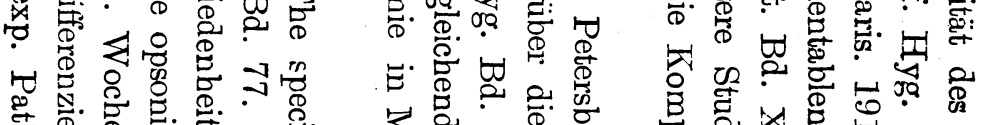

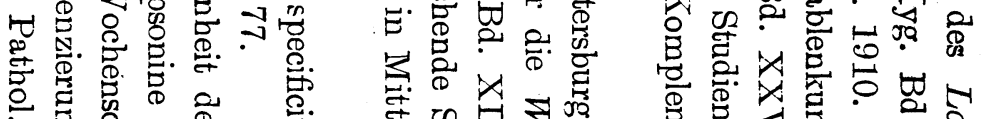

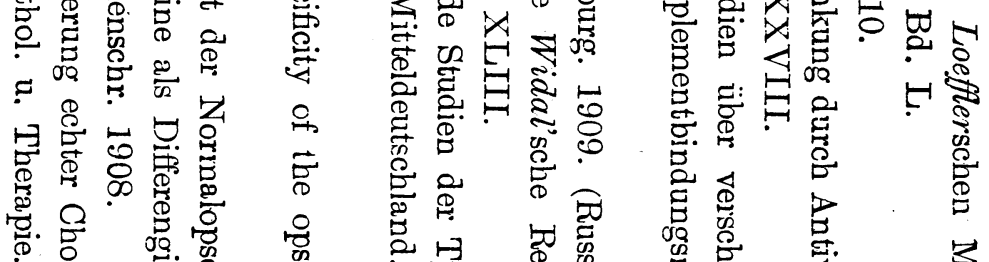

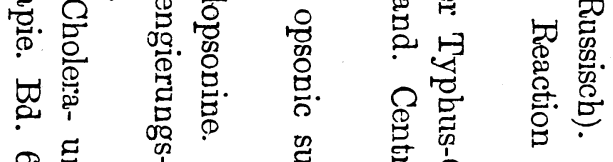

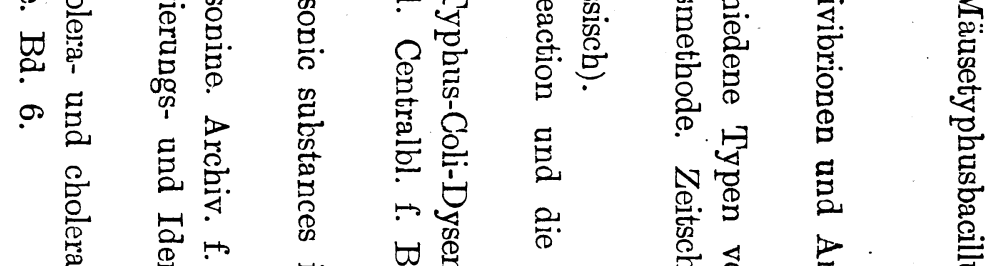

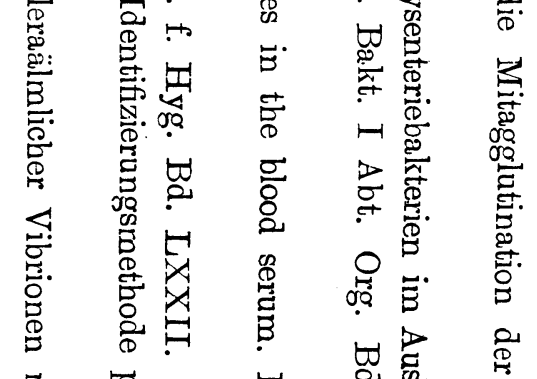

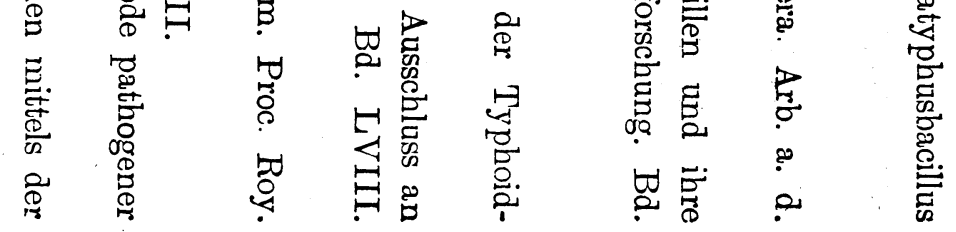

